\title{
PENERAPAN SUPERVISI AKADEMIK PENGAWAS PENDIDIKAN PADA MADRASAH ALIYAH KABUPATEN SIGI
}

\author{
Moh. Junaidin \\ Moh. Natsir Mahmud \\ Andi Rasdiyanah \\ Muh. Sain Hanafi \\ Kantor Wilayah Kementerian Agama Provinsi Sulawesi Tengah \\ Email: mohjunaidin@gmail.com
}

\begin{abstract}
Tis study aims: (1) to describe and obtain empirical data about the application of academic supervision of Islamic Religious Education supervisors in Senior High School Sigi. Type is qualitative research, the research approach is the normative theological approach to formal juridical pedagogic approach, data sources namely primary data and secondary data, data collection techniques through observation, interviews (interviews), and documentation. research instruments, namely, observation guides, interview guidelines and documentation references, data processing and analysis techniques, namely deductive analysis of comparative analysis of data verification, namely conclusions on data that have been presented testing the validity of the data, namely persistent observation, triangulation test, and checking

The results showed that the implementation of academic supervision of the Islamic Religious Education Supervisor at the Sigi District Islamic School went well because (a) the supervisor had the ability to plan academic supervision covering the whole process of thought and the determination of the mature way of activities to be carried out in carrying out academic supervision, in the context of achieving goals specifically for professional development of teachers in madrasas; and (b) the supervisor's ability has been optimized for the implementation of academic supervision through supervision of individuals and groups that greatly helped the professional maturity of teachers of Islamic Education Subjects in the Senior High School of Sigi Regency where as guidance to teachers in preparing syllabi and lesson plans; choosing and applying learning methods, managing using learning media, and guiding implementing learning evaluation.
\end{abstract}

Abstrak: Tulisan ini akan mengurai tentang penerapan supervisi akademik pengawas Pendidikan pada Madrasah Aliyah Kabupaten Sigi. Penelitian ini adalah penelitian kualitatif dengan lokasi di Madrasah Aliyah Kabupaten Sigi Propinsi Sulawesi Tengah. Pendekatan yang digunakan adalah pendekatan teologis normatif dan yuridis formal. Sumber data primer adalah data yang berasal dari pengawas, guru Mata Pelajaran Pendidikan Agama Islam, kepala madrasah, dan peserta didik. Data dikumpulkan dengan metode observasi, wawancara, dan dokumentasi dengan instrumen panduan observasi, acuan dokumentasi dan pedoman wawancara. Data diolah dan dianalisis dengan analisis deduktif, komparatif dan verifikasi data. Data diuji keabsahannya dengan presistent observation dan uji tringgulasi.

Hasil penelitian menunjukkan bahwa penerapan Supervisi Akademik Pengawas Pendidikan pada Madrasah Aliyah Kabupaten Sigi berjalan dengan 
baik karena (1) pengawas memiliki kemampuan merencakan supervisi akademik yang meliputi keseluruhan proses pemikiran dan penentuan cara yang matang dari kegiatan-kegiatan yang akan dikerjakan dalam melakukan supervisi akademik, dalam rangka pencapaian tujuan khususnya untuk pembinaan profesional guru di madrasah; dan (2) kemampuan pengawas telah pengoptimalan pelaksanaan supervisi akademik melalui supervisi individu dan kelompok yang sangat membantu kematangan profesional Guru Mata Pelajaran Pendidikan Agama Islam pada Madrasah Aliah Kabupaten Sigi dimana sebagai pembimbingan kepada guru dalam menyusun silabus dan RPP; memilih dan menerapkan metode pembelajaran, mengelola menggunakan media pembelajaran, dan pembimbingan melaksnakan evaluasi pembelajaran.

\section{Keywords: Supervisi Akademik, Pengawas Pendidikan, Madrasah Aliyah Sigi}

\section{PENDAHULUAN}

Salah satu upaya pemerintah untuk membentuk guru yang profesional adalah memberi tugas pengawas dalam mengawasi dan membantu guru pada proses pendidikan di sekolah. Kinerja pengawas dapat membantu meningkatkan profesional guru, sebaliknya jika pengawas tidak memiliki kinerja yang baik merupakan salah satu mata rantai penyebab rendahnya mutu pendidikan nasional. Untuk melaksanakan kinerja dengan baik diperlukan pengawas yang sesuai dengan kriteria yang telah ditetapkan dalam Peraturan Pemerintah Repoblik Indonesia Nomor 19 Tahun. 2005 Tentang Standar Nasional Pendidikan Bab VI Standar Pendidik dan tenaga Kependidikan, pasal 39 ayat 2 menyatakan bahwa:

1. Pengawasan pada pendidikan formal dilakukan oleh pengawas satuan pendidikan.

2. Kriteria minimal untuk menjadi pengawas satuan pendidikan meliputi:

a. Berstatus sebagai guru sekurang-kurangnya 8 (delapan) tahun atau kepala sekolah sekurang-kurangnya 4 (empat) tahun pada jenjang pendidikan yang sesuai dengan satuan pendidikan yang diawasi;

b. Memiliki sertifikat pendidikan fungsional sebagai pengawas satuan pendidikan;

c. Lulus seleksi sebagai pengawas satuan pendidikan. ${ }^{1}$

Pengawas pendidikan merupakan salah satu tenaga kependidikan dengan tugas pokok membantu pengembangan profesional guru dan mengawasi pelaksanaan pendidikan dan pembelajaran di sekolah. Supervisi pendidikan memegang kaidah akademik, treatment-nya berasaskan kaidah-kaidah keilmuan. Sasaran utamanya kegiatan akademik, membantu menciptakan situasi pembelajaran yang lebih kondusif. Supervisi berangkat dari sisi kelebihan guru, dari inovasi-inovasi yang dilakukannya, kemudian dikembangkan menjadi kemajuan yang berarti. Supervisi merupakan bant uan dan bimbingan terhadap guru untuk membantu mengatasi dan memecahkan masalah yang dihadapinya.

Supervisi sebagai bantuan pengembangan situasi pembelajaran agar lebih baik atau supervisi sebagai pelayanan supervisi manajerial dan akademik. PP RI No19

\footnotetext{
${ }^{1}$ Republik Indonesia, Undang-Undang RI Sistem Pendidikan Nasional Nomor. 20 Tahun 2003, h. 81 .
} 
Tahun 2005 Tentang Standar Nasional Pendidikan Bab VIII Standar Pengelolaan, Pasal 57 menyatakan bahwa:

Supervisi yang meliputi supervisi manajerial dan akademik dilakukan secara teratur dan berkesinambungan oleh pengawas atau penilik satuan pendidikan dan kepala satuan pendidikan. ${ }^{2}$

Kegiatan pengawas dalam supervisi pembelajaran merupakan kegiatan yang wajib dilaksanakan dalam penyelenggaraan pendidikan. Karena pengawas yang melaksanakan supervisi pembelajaran bertujuan mengembangkan iklim yang kondusif dan lebih baik dalam kegiatan pembelajaran, melalui pembinaan dan peningkatan profesional guru.

Pengawas melaksanakan supervisi di sekolah pada hakikatnya memberikan bantuan yang ditujukan kepada perbaikan dan pembinaan aspek pembelajaran sehingga memahami lingkungan pendidikan yang lebih luas sehingga dapat diasumsikan bahwa supervisi sekolah meliputi semua fungsi dan masalah yang ada sangkutpautnya dengan peningkatan profesional guru.

Ketentuan yang ada pada Undang-undang Sistem Pendidikan Nasional menunjukkan bahwa supervisi dari pengawas memiliki peranan penting untuk mencapai tujuan pendidikan, karena jika terjadi penyimpangan-penyimpangan para pendidik, pengawas akan meluruskan agar mereka melakukan tindakan-tindakan yang terarah pada pencapaian tujuan yang ditetapkan. Pengawas pendidikan diharapkan mengetahui dengan tepat masalah-masalah yang terjadi di sekolah sebab pengawas bertanggung jawab untuk mengontrol berhasil atau tidaknya pendidikan. Dapat diketahui bahwa tugas utama pengawas sekolah yaitu mewujudkan usaha perbaikan pendidikan terhadap komponen atau unsur-unsur itu sendiri.

Supervisi berfungsi membantu (Assisting) memberi Support (Supporting) dan mengajak mengikutsertakan (Sharing). ${ }^{3}$ Dilihat dari fungsinya, tampak jelas peranan supervisi itu. Seorang supervisor dapat berperan sebagai: koordinator; mengkoordinir bawahannya, konsultan; sebagai penampung aspirasi bawahannya, pemimpin kelompok; diharapkan bisa memimpin bawahannya, evaluator; mengevaluasi semua kegiatan yang telah dilaksanakan, maka dibutuhkan kompetensi pengawas dalam melaksanakan tugas pembinaan profesionalisme guru.

Kompetensi pengawas menurut Finch \& Crunkilton yang dikutip oleh Mulyasa mengartikan kompetensi sebagai penguasaan terhadap tugas pengawas, keterampilan, sikap, dan apresiasi yang diperlukan untuk menunjang keberhasilan pelaksanaan supervisi pendidikan. ${ }^{4}$

Kegiatan supervisi idealnya bukan sekedar untuk mengawasi dan menilai kemampuan guru, melainkan untuk membina dan mengembangkan profesional guru di madrasah. Hal ini tidak biasa terwujud jika dilaksanakan hanya sekedar sebagai formalitas saja. Para pengawas hanya datang sesuai jadwal yang ditentukan dengan

\footnotetext{
${ }^{2}$ Republik Indonesia, Undang-Undang RI Sistem Pendidikan Nasional Nomor. 20 Tahun 2003), h. 89 .

${ }^{3}$ Piet A. Sahertian, Prinsip dan Teknik Supervisi Pendidikan (Cet. I; Surabaya: Usaha Nasional, 1981), h. 31.

${ }^{4}$ Mulyasa, Kurikulum Berbasis Kompetensi Konsep, Karakteristik, dan Implementasi (Cet. XII; Bandung: Remaja Rosdakarya, 2015), h. 38.
} 
membawa instrumen pengukuran dan kemudian setelah dilaksanakan berarti tugasnya telah selesai.

Kajian dalam tulisan ini akan mengurai tentang penerapan supervisi akademik pengawas Pendidikan pada Madrasah Aliyah Kabupaten Sigi. Hasil observasi awal berkaiatan dengan kompetensi pengawas pendidikan pada Madrasah Aliyah di Kabupaten Sigi menunjukkan bahwa pada aspek personal pengawas memiliki kemampuan hubungan personal dan sosial yang harmonis. Akan tetapi, kunjungan yang dilakukan oleh pengawas di madrasah selama ini cenderung menitikberatkan pada pelaksanaannya masih berorientasi administratif, supervisi akademik identik dengan penilaian atau inspeksi terhadap para guru. Karena dalam praktik mengawasi dan menilai apa yang dikerjakan oleh guru, hanya mencari kekurangan dan kesalahan para guru, pengamatannya masih terhadap lingkup fisik material yang mudah diamati, tidak pada pembelajaran yang ditangani guru. Pengawas hanya datang membawa instrumen penilaian kemuadian menilai guru, mengecek apa saja ketentuan yang sudah dilaksanakan dan yang belum, tanpa menyampaikan kepada guru bahwa dari segi apa yang telah memenuhi kriteria penilaian dan yang belum, sehingga bobot kegiatan pengawas sangat bersifat administratif.

\section{KAJIAN TEORETIK}

\section{A. Konsep Supervisi Akademik}

Supervisi akademik menitikberatkan pada pengamatan terhadap kegiatan akademik, berupa pembelajaran baik di dalam maupun di luar kelas.

\section{Supervisi Akademik}

Supervisi akademik tidak bisa terlepas dari penilaian unjuk kerja guru dalam mengelola pembelajaran. Supervisi akademik merupakan serangkaian kegiatan dalam membantu guru mengembangkan kemampuannya mengelola proses pembelajaran, maka menilai unjuk kerja guru dalam mengelola proses pembelajaran merupakan salah satu kegiatan yang tidak bisa dihindarkan prosesnya.

Tujuan supervisi akademik adalah membantu guru mengembangkan kemampuannya mencapai tujuan pembelajaran yang dicanangkan bagi peserta didik. Melalui supervisi akademik diharapkan kualitas akademik yang dilakukan oleh guru semakin meningkat. Pengembangan kemampuan dalam konteks ini janganlah ditafsirkan secara sempit, semata-mata ditekankan pada peningkatan pengetahuan dan keterampilan mengajar guru, melainkan juga pada peningkatan komitmen dan kemauan atau motivasi guru, sebab dengan meningkatkan kemampuan dan motivasi kerja guru, kualitas pembelajaran akan meningkat. ${ }^{5}$

Supervisi akademik diselenggarakan dengan maksud membantu guru mengembangkan kemampuan profesionalnnya dalam memahami akademik, kehidupan kelas, mengembangkan keterampilan mengajarnya dan menggunakan kemampuannya melalui teknik-teknik tertentu. Supervisi akademik diselenggarakan dengan maksud untuk memonitor kegiatan pembelajaran di madrasah. Kegiatan memonitor ini bisa dilakukan melalui kunjungan kepala madrasah ke kelas-kelas di saat guru sedang mengajar, percakapan pribadi dengan guru, teman sejawatnya, maupun dengan sebagian peserta didiknya.

${ }^{5}$ Jerry Makawimbang, Supervisi dan Peningkatan Mutu Pendidikan (Cet. I; Bandung: Alfabeta, 2011), h. 99. 
Supervisi akademik diselenggarakan untuk mendorong guru menerapkan kemampuannya dalam melaksanakan tugas-tugas mengajarnya, mendorong guru mengembangkan kemampuannya sendiri, serta mendorong guru agar ia memiliki perhatian yang sungguh-sungguh (commitment) terhadap tugas dan tanggung jawabnya. Supervisi akademik yang baik adalah supervisi akademik yang mampu berfungsi mencapai multi tujuan.

Berikut uraian tentang pelaksaan supervisi akademik yang meliputi supervisi individu dan kelompok

a. Supervisi Individual

Supervisi individual adalah kegiatan yang dilakukan oleh kepala madrasah dalam rangka membantu guru dan tenaga kependidikan lainnya secara individu guna meningkatkan mutu, efektivitas penyelenggaraan pendidikan dan pembelajaran. ${ }^{6}$ Teknik supervisi individual, adalah teknik pelaksanaan supervisi yang digunakan kepala madrasah kepada guru secara individu guna peningkatan kualitas pembelajaran di kelas. ${ }^{7}$

Supervisi individual difokuskan membina, membantu, membimbing dan mengevaluasi guru secara individu guna perbaikan pembelajaran khususnya kepada guru tertentu yang mempunyai masalah khusus dan bersifat perorangan. Kepala madrasah sebagai supervisor hanya berhadapan seorang guru yang dipandang memiliki persoalan tertentu.

Pelaksanaan supervisi individual meliputi: kunjungan kelas, observasi kelas, pertemuan individual, kunjungan antar kelas, menilai diri sendiri, demonstrasi mengajar, dan buletin supervisi.

1) Pelaksanaan Kunjungan Kelas

Kunjungan kelas adalah teknik pembinaan guru oleh kepala madrasah, dalam rangka mengamati pelaksanaan proses pembelajaran, sehingga memperoleh data yang diperlukan dalam rangka pembinaan guru. Tujuan kunjungan kelas ini adalah untuk menolong guru dalam mengatasi kesulitan atau masalah guru di dalam kelas. Melalui kunjungan kelas, kepala madrasah akan membantu permasalahan yang dialaminya. Kunjungan kelas dapat dilakukan dengan pemberitahuan atau tanpa pemberitahuan terlebih dahulu, dan bisa juga atas dasar undangan dari guru.

Pelaksanaan kunjungan kelas, terdapat empat tahap yaitu, (a) tahap persiapan, pada tahap ini, kepala madrasah merencanakan waktu, sasaran, dan cara mengobservasi selama kunjungan kelas, (b) tahap pengamatan, yaitu mengamati jalannya proses pembelajaran berlangsung, (c) tahap akhir kunjungan, pada tahap akhir ini kepala madrasah bersama guru mengadakan perjanjian untuk membicarakan hasil observasi, dan dilakukan tindak lanjut. ${ }^{8}$

Ada beberapa kriteria kunjungan kelas yang baik yaitu, (a) memiliki tujuantujuan tertentu, (b) mengungkapkan aspek-aspek yang dapat memperbaiki kemampuan guru, (c) menggunakan instrumen observasi tertentu untuk mendapatkan daya yang obyektif, (d) pelaksanaan kunjungan kelas tidak menganggu proses pembelajaran, (e)

\footnotetext{
${ }^{6}$ Jerry Makawimbang, Supervisi dan Peningkatan Mutu Pendidikan, h. 101.

${ }^{7}$ Jerry Makawimbang, Supervisi dan Peningkatan Mutu Pendidikan, h. 187.

${ }^{8}$ Soemanto Wasty, Kepemimpinan dan Supervisi Pendidikan (Cet. V; Malang: Bumi Aksara, 2002), h. 90.
} 
terjadi interaksi antara pembina dan yang dibina sehingga menimbulkan sikap saling pengertian, (f) pelaksanaannya diikuti dengan program tindak lanjut. ${ }^{9}$

Kunjungan kelas dilakukan untuk memperoleh data tentang keadaan sebenarnya mengenai kemampuan dan ketrampilan guru dalam mengajar. Kemudian melakukan perbincangan untuk mencari pemecahan atas kesulitan-kesulitan yang dihadapi oleh guru. Sehingga kegiatan pembelajaran dapat ditingkatkan.

2) Pelaksanaan Observasi Kelas

Teknik observasi kelas dilakukan pada saat guru mengajar. Supervisor mengobservasi kelas dengan tujuan untuk memperoleh data tentang segala sesuatu yang terjadi dalam proses pembelajaran. ${ }^{10}$ Data ini sebagai dasar bagi supervisor melakukan pembinaan terhadap guru yang diobservasi. Tentang waktu supervisor mengobservasi kelas ada yang diberitahu dan ada juga tidak diberi tahu sebelumnya, tetapi setelah melalui izin supaya tidak mengganggu proses pembelajaran.

Secara umum yang diamati selama proses pembelajaran adalah:

a) Usaha-usaha dan aktivitas guru dengan peserta didik dalam proses pembelajaran

b) Cara penggunaan media pembelajaran

c) Reaksi mental para peserta didik dalam proses pembelajaran

d) Keadaan media pembelajaran yang dipakai dari segi materialnya. ${ }^{11}$

Pelaksanaan observasi kelas dilakukan beberapa tahap, yaitu:

a) Persiapan observasi kelas

b) Pelaksanaan observasi kelas

c) Penutupan pelaksanaan observasi kelas

d) Penilaian hasil observasi

e) Tindak lanjut. ${ }^{12}$

Selama berada di kelas supervisor melakukan pengamatan dengan teliti, dan menggunakan instrumen observasi tertentu, antara lain evaluative check-list, activity check-list.

Tujuan yang dikehendaki dalam observasi kelas antara lain adalah untuk:

a) Mempelajari material yang dipelajari oleh peserta didik, validitasnya terhadap tujuan pendidikan, faedah, minat, serta nilainya untuk peserta didik.

b) Mempelajari usaha-usaha yang dipergunakan dalam menemukan, mendiagnosa, serta memperbaiki kesulitan-kesulitan belajar yang dihadapi oleh peserta didik.

c) Mempelajari usaha-usaha guru untuk mendorong dan menuntun peserta didik untuk belajar, prinsip-prinsip yang dipergunakan dan aplikasinya dalam materi umum dan materi khusus bagi peserta didik dalam proses pembelajaran.

d) Mempelajari usaha-usaha yang dipakai untuk menilai hasil belajar, sifat dan alat metode pengukuran serta hubungannya dengan tujuan dari situasi pembelajaran, namun bukan mencatat kesalahan-kesalahan guru guna tujuan-tujuan lain. ${ }^{13}$

Observasi yang dilakukan bukan untuk mencari kesalahan, akan tetapi untuk

\footnotetext{
${ }^{9}$ Soemanto Wasty, Kepemimpinan dan Supervisi Pendidikan, h. 91.

${ }^{10}$ Syaiful Sagala, Supervisi Pembelajaran dalam Profesi Pendidikan; Membantu Mengatasi Kesulitan Guru Memberikan Layanan Belajar yang Bermutu (Cet. II; Bandung: CV. Alfabeta, 2010), h. 188.

${ }^{11}$ E. Kastomo, Supervisi Pendidikan (Cet. II; Bandung: Alfabeta, 2007), h. 98.

${ }^{12}$ E. Kastomo, Supervisi Pendidikan, h. 102.

${ }^{13}$ E. Kastomo, Supervisi Pendidikan, h. 111.
} 
meningkatkan kualitas pembelajaran setelah menemukan titik lemah melalui observasi tersebut. Tujuan dari observasi kelas ialah ingin memperoleh data tentang segala sesuatu yang terjadi di dalam proses pembelajaran. Melalui data tersebut, supervisor dapat melakukan pembinaan terhadap guru yang diobservasi.

3) Pelaksanaan Pertemuan Individual

Pertemuan individual adalah satu pertemuan, percakapan, dialog, dan tukar pikiran antara pembina atau supervisor guru, guru dengan guru, mengenai usaha meningkatkan kemampuan profesional guru. Tujuannya adalah: (1) memberikan kemungkinan pertumbuhan jabatan guru melalui pemecahan masalah yang dihadapi; (2) mengembangkan hal mengajar yang lebih baik; (3) memperbaiki segala kelemahan dan kekurangan pada diri sendiri; dan (4) menghilangkan atau menghindari segala prasangka yang bukan-bukan. ${ }^{14}$

Percakapan pribadi bisa berupa percakapan secara perorangan antara supervisor dengan guru pertemuan individual itu bisa berupa percakapan antara kepala madrasah dengan guru. Ada beberapa macam percakapan pribadi yang dapat dibudayakan di madrasah: Pertama, percakapan pribadi setelah kunjungan. Pengamatan terhadap guru yang sedang mengelola proses pembelajaran, kepala madrasah tersebut mengadakan percakapan pribadi dengan guru yang telah diobservasi dalam rangka membicarakan apa yang telah diamati; kedua, percakapan pribadi sehari-hari yang disebut juga percakapan informal. Pertemuan informal adalah pertemuan yang tidak direncanakan waktu dan tempatnya. Pertemuan bisa terjadi sewaktu-waktu dan dimana saja bila diperlukan. Dalam pertemuan informal guru lebih melakukan ekspresi dibandingkan dengan pertemuan formal. Dalam percakapan ini supervisor berusaha menyadarkan guru akan kelebihan dan kekurangannya mendorong agar yang sudah baik lebih di tingkatkan dan yang masih kurang agar diupayakan untuk memperbaikinya.

Pertemuan formal adalah pertemuan yang sengaja diadakan pada waktu tertentu, yang dihadiri guru dengan supervisornya. Topik yang dibahas berupa hasil observasi supervisor terhadap aktivitas guru dalam kelas, atau dapat juga berupa topik yang lain.

4) Pelaksanaan Kunjungan Antar Kelas

Kunjungan antar kelas dapat juga digolongkan sebagai teknik supervisi secara individu. Kegiatan ini dilakukan guru yang satu berkunjung ke kelas yang lain dalam lingkungan madrasah itu sendiri. Tujuan teknik kunjungan kelas sebagai berikut: (1) membantu guru yang belum berpengalaman, (2) membantu guru yang telah berpengalaman tentang kekeliruan yang dia lakukan, (3) membantu guru pindahan yang belum jelas tentang situasi dan kondisi kelas, (4) membantu melaksanakan proyek pendidikan, (5) mengamati perilaku guru pengganti dalam proses pembelajaran, (6) mendengarkan nara sumber mengajar, (7) mengamati tim pengajar melaksanakan tugasnya pada peserta didik dalam kelompok kecil/kelompok besar, (8) mengamati cara mengajar bidang studi yang istimewa, (9) membantu menilai pemakaian media pendidikan. ${ }^{15}$

Melalui kunjungan antar kelas ini diharapkan guru akan memperoleh pengalaman baru dari teman sejawatnya mengenai pelaksanaan proses pembelajaran, pengelolaan kelas, dan sebagainya. Agar kunjungan antar kelas ini dapat berhasil

\footnotetext{
${ }^{14}$ E. Kastomo, Supervisi Pendidikan, h. 103.

${ }^{15}$ Syaefuddin, Supervisi Pendidikan (Cet. III; Jakarta: Rineka Cipta, 2005), h. 79.
} 
dengan baik dan bermanfaat, maka harus ada beberapa hal yang diperhatikan antara lain:

a) Guru yang akan dikunjungi harus diseleksi dengan sebaik-baiknya. Diupayakan agar mencari guru yang berpengalaman sehingga mampu memberikan pengalaman baru bagi guru yang akan mengunjungi.

b) Tentukan guru yang akan mengunjungi.

c) Sediakan segala fasilitas yang diperlukan dalam kunjungan kelas.

d) Adakan tindak lanjut setelah kunjungan antar kelas selesai.

e) Supervisor/kepala madrasah hendaknya mengikuti dengan cermat. Amatilah apa-apa yang ditampilakn secara cermat, dan mencatatnya pada format-format tertentu.

f) Adakan tindak lanjut setelah kunjungan antar kelas selesai.

g) Segera aplikasikan ke madrasah atau ke kelas guru bersangkutan, yaitu dengan menyesuaikan pada situasi dan kondisi yang dihadapi.

h) Adakan perjanjian-perjanjian untuk mengadakan kunjungan antar kelas berikutnya. ${ }^{16}$

Kunjungan antar kelas adalah kegiatan saling mengunjungi antara guru yang satu dengan guru yang lainnya. Dalam hal ini, kepala madrasah dapat mendorong seorang guru, misalnya untuk mengunjungi guru lainnya. Bisa juga antar madrasah, di mana kepala madrasah mendorong guru untuk mengunjungi atau melihat guru madrasah terdekat dalam proses pembelajaran.

Supervisor dapat memanfaatkan pertemuan-pertemuan pendidikan untuk meningkatkan kualifikasi guru yang dibinanya. Dalam pertemuan tersebut supervisor bekerjasama dengan kepala madrasah dan semua stakeholder di madrasah.

5) Pelaksanaan Penilaian Diri Sendiri

Menilai diri sendiri merupakan satu teknik individual dalam supervisi pendidikan. Penilaian diri sendiri memberikan informasi secara obyektif kepada guru tentang peranannya di kelas dan memberikan kesempatan kepada guru mempelajari metode pembelajarannya dalam mempengaruhi peserta didik. Dengan demikian guru akan terdorong untuk mengembangkan diri secara profesional.

Ada beberapa cara/alat untuk menilai diri sendiri yaitu:

a) Mencatat peserta didik dalam suatu catatan, baik mereka bekerja secara perorangan maupun secara kelompok

b) Buat suatu pandangan atau pendapat yang disampaikan kepada peserta didik untuk menilai pekerjaan atau suatu aktivitas (buat dalam bentuk pertanyaan bisa pertanyaan tertutup atau terbuka dan tidak perlu menyebut nama)

c) Menganalisis tes terhadap unit kerja. ${ }^{17}$

Teknik ini berarti kepala madrasah supervisi kepada guru dengan cara menyarankan guru tersebut melakukan penilaian terhadap diri sendiri. Dengan melakukan penilaian terhadap diri sendiri diharapkan guru melihat keterbatasan dirinya dan berusaha mengatasinya. Tugas kepala madrasah adalah menyiapkan instrumen penilaian diri sendiri yang dapat digunakan guru.

Menilai diri sendiri merupakan tugas yang tidak mudah bagi guru, karena suatu pengukuran terbalik karena selama ini guru hanya menilai peserta didik. Menilai diri sendiri dapat memberikan nilai tambah pada hubungan guru dan supervisor, yang akan

\footnotetext{
${ }^{16}$ Soemanto Wasty, Kepemimpinan dan Supervisi Pendidikan, h. 103.

${ }^{17}$ Soemanto Wasty, Kepemimpinan dan Supervisi Pendidikan, h. 107.
} 
memberikan nilai positif bagi kegiatan pembelajaran.

6) Pelaksanaan Demonstrasi Mengajar

Demonstrasi mengajar adalah suatu upaya supervisor membantu guru yang disupervisi dengan menunjukkan kepada mereka bagimana mengajar yang baik. Usaha peningkatan pembelajaran dengan cara mendemonstrasikan atau cara mengajar dihadapan guru dalam mengenalkan berbagai aspek dalam mengajar di kelas oleh supervisor. $^{18}$ Dalam demonstrasi mengajar guru yang sukses dalam pekerjaannya diberi kesempatan oleh supervisor membantu guru yang lain dalam memperbaiki proses pembelajaran. Guru tersebut ditunjuk oleh supervisor sebagai partnernya dalam bidang keahlian mereka untuk membantu guru memajukan proses pembelajaran.

a. Supervisi Kelompok

Teknik supervisi kelompopk merupakan cara yang digunakan oleh supervisor untuk mencapai tujuan supervisi itu sendiri yang pada akhirnya dapat melakukan perbaikan pembelajaran yang sesuai dengan situasi dan kondisi. Teknik supervisi kelompok merupakan suatu metode atau cara melakukan hal-hal tertentu. Suatu teknik yang baik adalah terampil dan cepat. Seorang supervisor harus memilih teknik-teknik khusus yang serasi. Teknik sebagai suatu metode atau cara melakukan hal-hal tertentu.

Supervisi kelompok adalah teknik supervisi yang bersifat dilaksanakan dalam pembinaan guru secara bersama-sama oleh supervisor dengan sejumlah guru dalam satu kelompok. ${ }^{19}$ Teknik supervisi kelompok adalah yang diterapkan oleh supervisor untuk mencapai tujuan supervisi itu sendiri yang pada akhirnya dapat melakukan perbaikan pembelajaran yang sesuai dengan situasi dan kondisi.

Berdasarkan pengertian tersebut, berarti supervisi bukan ajang untuk menghakimi kesalahan atau kekurangan guru dan warga madrasah lainnya, tetapi sebuah upaya untuk memberikan peluang seluas-luasnya kepada seluruh warga madrasah untuk meningkatkan kualitas diri, mengekspresikan dan mengembangkan potensi diri. Upaya tersebut dilakukan dalam rangka membangun, mengembangkan, dan meningkatkan kualitas pembelajaran di madrasah, sebagai tujuan pendidikan.

Berikut pelaksanaan supervisi kelompok yang dilakukan oleh kepala madrasah yaitu mengawasi guru dengan aktifitas madrasah dengan mengendalikan usaha guru dalam mendidik para peserta didik agar berkembang secara total. Supervisi kelompok dilakukan untuk menjamin bahwa keseluruhan aktivitas penyelenggaraan organisasi dapat terlaksana dengan tingkat efesien, efektif dan produktifitas yang tinggi. Pelaksanaan supervisi kelompok tidak semata-mata menjadi tugas kepala madrasah, tetapi juga menjadi tugas pejabat-pejabat struktural, yang karena bidang tugasnya dalam ruang lingkup madrasah.

Pelaksanaan supervisi kelompok adalah semua teknik supervisi yang digunakan dalam memberikan supervisi kepada guru secara berkelompok. Beberapa teknik supervisi secara kelompok yaitu kepanitiaan, mengikuti kursus, kurikulum, bacaan

\footnotetext{
${ }^{18}$ Syaiful Sagala, Supervisi Pembelajaran dalam Profesi Pendidikan, h. 90.

${ }^{19}$ Piet A. Sahertian, Konsep Dasar dan Teknik Supervisor Pendidikan dalam Rangka Pengembangan Sumber Daya Manusia (Cet. II; Jakarta: Rineka Cipta, 2001), h. 86.
} 
terpimpin, demonstrasi pembelajaran, perjalanan staf, kuliah, diskusi panel, perpustakaan profesional, buletin supervisi, pertemuan guru, lokakarya. ${ }^{20}$

Berbagai macam teknik dapat digunakan oleh supervisor dalam membantu guru meningkatkan situasi pembelajaran, baik secara kelompok maupun secara perorangan ataupun dengan cara langsung bertatap muka dan cara tak langsung bertatap muka atau melalui media komunikasi.

Sagala mengemukakan teknik-teknik supervisi kelompok yaitu pertemuan orientasi, rapat guru, studi kelompok antar guru, diskusi, workshop, tukar menukar pengalaman, diskusi kelompok, seminar, dan simposium. ${ }^{21}$ Sebagai berikut:

1) Pelaksanaan Orientasi

Sahertian mengemukakan pada pertemuan orientasi supervisor diharapkan dapat menyampaikan atau menguraikan kepada guru hal-hal sebagai berikut:

a) Sistem kerja yang berlaku di madrasah itu.

b) Proses dan mekanisme administrasi dan organisasi madrasah.

c) Biasanya diiringi dengan tanya jawab dan penyajian seluruh kegiatan dan situasi madrasah.

d) Sering juga pertemuan orientasi ini juga diikuti dengan tindak lanjut dalam bentuk diskusi kelompok dan lokakarya.

e) Ada juga melalui perkunjungan ke tempat-tempat tertentu yang berkaitan atau berhubungan dengan sumber belajar.

f) Salah satu ciri yang sangat berkesan bagi pembinaan segi sosial dalam orientasi ini adalah makan bersama.

g) Aspek lain yang membantu terciptanya suasana kerja ialah guru baru tidak merasa asing tetapi guru baru merasa diterima dalam kelompok guru lain. ${ }^{22}$

Pertemuan orientasi merupakan pertemuan antara supervisor dengan yang disupervisi yang bertujuan menghantar guru memasuki suasana kerja yang baru.

2) Pelaksanaan Rapat Guru

Tujuan teknik supervisi rapat guru sebagai berikut:

a) Menyatukan pandangan-pandangan guru tentang masalah-masalah dalam mencapai makna dan tujuan pendidikan.

b) Memberikan motivasi kepada guru untuk menerima dan melaksanakan tugastugasnya dengan baik serta dapat mengembangkan diri dan jabatan mereka secara maksimal.

c) Menyatukan pendapat tentang metode kerja yang baik guna pencapaian pembelajaran yang maksimal.

d) Membicarakan sesuatu melalui rapat guru yang bertalian dengan proses pembelajaran.

e) Menyampaikan informasi baru seputar belajar dan pembelajaran, kesulitankesulitan mengajar, dan cara mengatasi kesulitan mengajar secara bersama dengan semua guru dimadrasah. ${ }^{23}$

\footnotetext{
${ }^{20}$ Ary Gunawan, Supervisi dan Peningkatan Mutu Pendidikan (Cet. II; Yogyakarta: Adicita Karya Nusa, 2001), h. 56.

${ }^{21}$ Syaiful Sagala, Supervisi Pembelajaran dalam Profesi Pendidikan, h. 175.

${ }^{22}$ Piet A. Sahertian, Konsep Dasar dan Teknik Supervisi Pendidikan dalam Rangka Pengembangan Sumber Daya Manusia, h. 86.
} 
Beberapa hal yang harus diperhatikan dalam suatu rapat guru antara lain: (a) Tujuan yang hendak dicapai harus jelas dan konkrit, (b) masalah-masalah yang akan menjadi bahan rapat harus merupakan masalah yang timbul dari guru yang dianggap penting dan sesuai dengan kebutuhan mereka, (c) masalah pribadi yang menyangkut guru di lembaga pendidikan tersebut perlu mendapat perhatian, (d) pengalaman baru yang diperoleh dalam rapat tersebut harus membawa mereka pada peningkatan pembelajaran terhadap peserta didik, (e) partisipasi guru pada pelaksanaan rapat hendaknya dipikirkan dengan sebaik-baiknya, (f) persoalan kondisi setempat, waktu, dan tempat rapat menjadi bahan pertimbangan dalam perencanaan rapat guru. ${ }^{24}$ Rapat guru merupakan teknik supervisi kelompok melalui rapat guru yang dilakukan untuk membicarakan proses pembelajaan, dan upaya atau cara meningkatkan profesi guru.

3) Pelaksanaan Studi Kelompok Antar Guru

Tujuan pelaksanaan teknik supervisi ini adalah, (a) meningkatkan kualitas penguasaan materi dan kualitas dalam memberi layanan belajar, (b) memberi kemudahan bagi guru untuk mendapatkan bantuan pemecahan masalah pada materi pembelajaran, (c) bertukar pikiran dan berbicara dengan sesama guru pada satu bidang studi atau bidang-bidang studi yang serumpun. ${ }^{25}$

Studi kelompok antara guru adalah suatu kegiatan yang dilakukan oleh sejumlah guru yang memiliki keahlian dibidang studi tertentu, seperti MIPA, Bahasa, IPS dan sebagainya, dan dikontrol oleh supervisor agar kegiatan dimaksud tidak berubah menjadi ngobrol hal-hal yang tidak ada kaitannya dengan materi. Topik yang akan dibahas dalam kegiatan ini telah dirumuskan dan disepakati terlebih dahulu.

4) Pelaksanaan Diskusi

Diskusi adalah pertukaran pikiran atau pendapat melalui suatu percakapan tentang suatu masalah untuk mencari alternatif pemecahannya. Diskusi merupakan salah satu teknik supervisi kelompok yang duterapkan untuk mengembangkan berbagai ketrampilan pada diri para guru dalam mengatasi berbagai masalah atau kesulitan dengan cara melakukan tukar pikiran antara satu dengan yang lain.

Hal-hal yang harus diperhatikan supervisor sebagai pemimpin diskusi sehingga setiap anggota mau berpartisipasi selama diskusi berlangsung supervisor harus mampu:

a) Menentukan tema perbincangan yang lebih spesifik.

b) Melihat bahwa setiap anggota diskusi senang dengan keadaan dan topik yang dibahas dalam diskusi.

c) Melihat bahwa masalah yang dibahas dapat dimengerti oleh semua anggota dan dapat memecahkan masalah dalam pembelajaran.

d) Melihat bahwa kelompok merasa diperlukan dan diikutsertakan untuk mencapai hasil bersama.

e) Mengakui pentingnya peranan setiap anggota yang dipimpinnya. ${ }^{26}$

Melalui teknik ini supervisor dapat membantu para guru untuk saling mengetahui, memahami, dan mendalami suatu permasalahan, sehingga secara bersama-

\footnotetext{
${ }^{23}$ Made Pidarta, Pemikiran Tentang Supervisi Pendidikan (Jakarta: Bumi Aksara, 2009), h. 71.

${ }^{24}$ Syaiful Sagala, Supervisi Pembelajaran dalam Profesi Pendidikan, h. 177.

${ }^{25}$ Kasman, "Model Supervisi Individu dan Kelompok dalam Supervisi Pembelajaran”, AlBuhust (Malang: Jurnal Penelitian, 2010), h. 29.

${ }^{26}$ Kasman, "Model Supervisi Individu dan Kelompok dalam Supervisi Pembelajaran", AlBuhust, h. 30 .
} 
sama akan berusaha mencari alternatif pemecahan masalah tersebut. Tujuan pelaksanaan supervisi diskusi adalah untuk memecahkan masalah-masalah yang dihadapi guru dalam pekerjaannya sehari-hari dan upaya meningkatkan profesi melaluii diskusi.

\section{5) Pelaksanaan Workshop}

Workshop adalah suatu kegiatan belajar kelompok yang terjadi dari sejumlah pendidik yang sedang memecahkan masalah melalui percakapan dan bekerja secara kelompok. Hal-hal yang perlu diperhatikan pada waktu pelaksanaan workshop antara lain (a) masalah yang dibahas muncul dari guru tersebut; (b) selalu menggunakan secara maksimal aktivitas mental dan fisik dalam kegiatan sehingga tercapai perubahan profesi yang lebih tinggi dan lebih baik. ${ }^{27}$

6) Pelaksanaan Diskusi Kelompok

Sesuai dengan paradigma baru manajemen madrasah yaitu pemberdayaan dan partisipasi, maka keberhasilan atau kegagalan sebuah madrasah dalam melaksanakan program atau mencapai standar bukan hanya menjadi otoritas kepala madrasah. Hasil monitoring yang dilakukan kepala madrasah hendaknya disampaikan secara terbuka kepada pihak madrasah, terutama kepala madrasah, wakil kepala madrasah, komite madrasah dan guru. Secara bersama-sama pihak madrasah dapat melakukan refleksi terhadap data yang ada, dan menemukan sendiri faktor-faktor penghambat serta pendukung yang selama ini mereka rasakan. ${ }^{28}$

Agar kegiatan proses pengumpulan informasi suatu masalah atau sering disebut Fokus Group Discussion (FGD) dapat berjalan efektif, maka diperlukan langkahlangkah sebagai berikut:

a) Semua peserta sebelum $F G D$ dilaksanakan sudah mengetahui maksud diskusi serta permasalahan yang akan dibahas.

b) Anggota $F G D$ hendaknya mewakili berbagai unsur, sehingga diperoleh pandangan yang berragam dan komprehensif.

c) Pimpinan $F G D$ hendaknya akomodatif dan berusaha menggali pikiran/ pandangan peserta dari sudut pandang masing-masing unsur.

d) Notulen hendaknya benar-benar teliti dalam mendokumentasikan usulan atau pandangan semua pihak.

e) Pimpinan FGD hendaknya mampu mengontrol waktu secara efektif, dan mengarahkan pembicaraan agar tetap fokus pada permasalahan.

f) Apabila dalam satu pertemuan belum diperoleh kesimpulan atau kesepakatan, maka dapat dilanjutkan pada putaran berikutnya. Untuk ini diperlukan catatan mengenai hal-hal yang telah dan belum disepakati. ${ }^{29}$

Diskusi kelompok terfokus ini dapat dilakukan dalam beberapa putaran sesuai dengan kebutuhan. Tujuan dari $F G D$ adalah untuk menyatukan pandangan stakeholder

\footnotetext{
Buhust, h. 31.

${ }^{27}$ Kasman, "Model Supervisi Individu dan Kelompok dalam Supervisi Pembelajaran", AlBuhust, h. 32.

${ }^{28}$ Kasman, "Model Supervisi Individu dan Kelompok dalam Supervisi Pembelajaran", Al-

${ }^{29}$ Kasman, "Model Supervisi Individu dan Kelompok dalam Supervisi Pembelajaran", AlBuhust, h. 36.
} 
mengenai realitas kondisi (kekuatan dan kelemahan) madrasah, serta menentukan langkah-langkah operasional yang akan diambil untuk memajukan madrasah. Peran kepala madrasah adalah sebagai fasilitator sekaligus menjadi narasumber apabila diperlukan, untuk memberikan masukan berdasarkan pengetahuan dan pengalamannya.

\section{7) Pelaksanaan Seminar}

Seminar adalah suatu rangkaian kajian yang diikuti oleh suatu kelompok untuk mendiskusikan, membahas dan memperdebatkan suatu masalah yang berhubungan dengan topik. Berkaitan dengan pelaksanaan supervisi, dalam seminar ini dapat dibahas seperti bagaimana menyusun silabus sesuai standar isi, bagaimana mengatasi masalah disiplin sebagai aspek moral madrasah, bagaimana mengatasi peserta didik yang selalu membuat keributan di kelas dan masalah lainnya. Pada waktu pelaksanaan seminar kelompok mendengarkan laporan atau ide menyangkut permasalahan pendidikan dari salah seorang anggotanya. ${ }^{30}$

8) Pelaksanaan Simposium

Kegiatan mendatangkan seorang ahli pendidikan untuk membahas masalah pendidikan. Simposium menyuguhkan pidato-pidato pendek yang meninjau suatu topik dari aspek-aspek yang berbeda. Penyuguh pidato biasanya tiga orang dimana guru sebagai pengikut diharapkan dapat mengambil bekal dengan mendengarkan pidatopidato tersebut. $^{31}$

Beberapa teknik supervisi kelompok yang mengarahkan dan mempermudah supervisor dalam proses supervisi kelompok. Supervisor yang efektif seharusnya menyadari adanya beberapa teknik supervisi dan berusaha menguasai satu atau lebih teknik sesuai dengan perhatian guru yang akan supervisi. Menggunakan setiap teknik memiliki kelebihan dan kekurangan. Akan tetapi kelebihan-hkelebihan setiap teknik dengan cepat akan hilang apabila supervisor lebih berwawasan terhadap hanya satu teknik yang dipahami dan disukai dengan tidak mengikuti perhatian guru.

\section{B. Konsep Pengawas Pendidikan}

\section{Pengertian Pengawas Pendidikan}

Pengawas pendidikan adalah Pegawai Negeri Sipil (PNS) yang diberi tugas, tanggung jawab dan wewenang secara penuh oleh pejabat yang berwenang untuk melakukan pengawasan di madrasah dengan melakukan penilaian dan pembinaan dari segi teknis pendidikan dan administrasi pada satuan pendidikan prasekolah, pendidikan dasar dan menengah. ${ }^{32}$ Pengawas merupakan pejabat yang diberi tugas untuk melakukan pengawasan di sekolah dengan melaksanakan penilaian dan pembinaan dari segi teknis pendidikan dan administrasi pada satuan pendidikan.

Pengawas pendidikan adalah Pegawai Negeri Sipil yang diberi tugas (a) melakukan pembinaan pengembangan kualitas sekolah, kinerja kepala sekolah, kinerja guru, dan kinerja seluruh staf sekolah, (b) melakukan evaluasi dan monitoring pelaksanaan program sekolah beserta pengembangannya, (c) melakukan penilaian terhadap proses dan hasil program pengembangan sekolah secara kolaboratif dengan

\footnotetext{
${ }^{30}$ Syaiful Sagala, Supervisi Pembelajaran dalam Profesi Pendidikan, h. 181.

${ }^{31}$ Syaiful Sagala, Supervisi Pembelajaran dalam Profesi Pendidikan, h. 183.

${ }^{32}$ Departemen Agama RI, Profesionalitas Pelaksanaan Pengawasan Pendidikan, h. 18-19
} 
stakeholder sekolah. ${ }^{33}$

Pengawas pendidikan adalah pegawai negeri sipil yang bertugas dan tanggung jawab secara penuh untuk menstimulasi, mengkoordinasi dan membimbing secara kontinyu para guru di madrasah baik secara individual maupun secara kolektif, agar guru lebih mengerti dan lebih efektif dalam mewujudkan seluruh fungsi pembelajaran di madrasah. ${ }^{34}$ Sejalan dengan asumsi tersebut, secara umum pengawas pendidikan merupakan pemberian wewenang untuk membimbing guru dan membantu memperbaiki meningkatkan pengolahan madrasah sehingga tercipta kondisi kegiatan pembelajaran yang efektif.

Pengawas pendidikan yaitu pegawai negeri sipil yang diberi tugas, tanggung jawab, dan wewenang secara penuh untuk melakukan supervisi kepada kepada sekolah termasuk madrasah dalam semua tingkatan. ${ }^{35}$ Menurut Sagala pengawas pendidikan yaitu guru yang diangkat dan ditugaskan untuk memperbaiki situasi pendidikan atau pembelajaran, yakni sebagai bantuan bagi pendidik untuk meningkatkan profesional guru sehinnga peserta didik akan lebih berkualitas. ${ }^{36}$ Pengawas pendidikan dimaknai sebagai personil yang diberi tanggung jawab dan wewenang penuh untuk melaksanakan pengawasan akademik dan manajerial yang merupakan tangan panjang dari Kementrian Agama yang bersentuhan langsung dengan guru.

Pengawas pendidikan merupakan jabatan fungsional yang ditugaskan memimpin guru dan petugas-petugas lainnya di madrasah dalam memperbaiki pembelajaran, termasuk menstimulasi, menyeleksi pertumbuhan jabatan dan perkembangan guru serta merevisi tujuan-tujuan pendidikan, bahan pembelajaran dan metode serta evaluasi pembelajaran yang merupakan bagian yang tidak terpisahkan dari seluruh proses administrasi pendidikan, yang ditujukan terutama untuk mengembangkan efektifitas personalia madrasah yang berhubungan dengan tugas utama dalam usaha pendidikan. ${ }^{37}$

Pengawas pendidikan merupakan guru yang diangkat dalam jabatan pengawas yang bertugas melakukan penilaian dan pembinaan, dalam bentuk supervisi akademik, supervisi manajerial, melakukan pembimbingan dan pelatihan yang bertanggung jawab untuk melaksanakan penjaminan mutu, serta memberdayakan kepala sekolah dan guru yang menjadi binaannya melalui penilian (evaluation) dengan jalan penilitian (research) dan merupakan usaha perbaikan (improvement).

\section{Tugas Pengawas Pendidikan}

Tugas pengawas dalam Peraturan Menteri Agama Republik Indonesia Nomor 16 Tahun 2010 Tentang Pengelolaan Pendidikan Agama pada Madrasah Bab VI Pasal 19 Ayat 1, diuraikan bahwa pengawas pendidikan agama bertugas melakukan pengawasan terhadap terselenggaranya Pendidikan Agama Islam yang meliputi

\footnotetext{
${ }^{33}$ Mustafa Husba, Strategi Membangun Kinerja Supervisor Pendidikan (Cet. II; Makassar: Yapma Makassar, 2008), h. 27.

${ }^{34}$ Piet A. Sahertian, Konsep Dasar dan Teknik Supervisor Pendidikan dalam Rangka Pengembangan Sumber Daya Manusia (Cet. II; Jakarta: Rineka Cipta, 2001), h. 17.

${ }^{35}$ Husni Rahim, Profesionalitas Pegawai Pendais (Jakarta: Logos Wacana Ilmu, 2000), h. 15.

${ }^{36}$ Syaiful Sagala, Administrasi Pendidikan Kontemporer (Cet. XIIBandung: CV. Alfabeta, 2012), 228.

${ }^{37}$ Mustafa Husba, Strategi Membangun Kinerja Supervisor Pendidikan, h. 27.
} 
penilaian, pembinaan, pemantauan, penelitian, pelaporan dan tindak lanjut dalam rangka meningkatkan kualitas penyelenggaraan pendidikan agama sesuai dengan standar nasional pendidikan agar tercapai tujuan pendidikan agama dan tujuan pendidikan nasional. ${ }^{38}$

Tugas pengawas Pendidikan Agama Islam dalam Peraturan Menteri Agama RI Nomor 2 Tahun 2012 tentang Pengawas Madrasah dan Pengawas Pendidikan Agama Islam di Sekolah, bab II pasal 4, di antaranya:

a. Menyusun program pengawasan

b. Membina, membimbing, mengevaluasi dan mengembangkan profesi guru

c. Memantau penerapan standar nasional

d. Menilai hasil pelaksanaan program pengawasan dan

e. Melaporkan pelaksanaan tugas kepengawasan. ${ }^{39}$

Tugas pengawas pendidikan sesuai dengan Surat Keputusan Menteri Negara Pendayagunaan Aparatur Negara nomor 118/ 1996, bab II, pasal 3 ayat (1) dijelaskan bahwa tugas pokok Pengawas Pendidikan Agama Islam (PPAI) adalah menilai dan membina teknis pelaksanaan Pendidikan Agama Islam (PAI) di sekolah umum dan penyelenggara pendidikan di madrasah, baik negeri maupun swasta yang menjadi tanggung jawabnya. Adapun bidang pengawasan Pendidikan Agama Islam (PAI) di sekolah umum meliputi; TK, SD, SLTP, SMU, SMK dan SLB. Sedangkan pada madrasah meliputi: RA, BA, MI, MTS, MA dan MD baik negeri maupun swasta. ${ }^{40}$

Gambaran tersebut di atas dapat dipahami bahwa tugas pokok Pengawas Pendidikan Agama Islam mencakup dua lembaga pendidikan yang berbeda, yaitu di sekolah umum dalam lingkungan Kementerian Pendidikan dan Kebudayaan dan di madrasah dalam lingkungan Kementerian Agama, hal ini berarti bahwa apabila Pengawas Pendidikan Agama Islam (PPAI) melakukan pengawasan di sekolah umum, maka tugas pokoknya adalah menilai dan membina guru dan peserta didik dalam proses pembelajaran (pelaksanaan) mata pelajaran Pendidikan Agama Islam pada sekolah yang bersangkutan dan pengawasan yang dilakukan adalah pengawasan/ supervisi teknis kependidikan dan sedikit melakukan administrasi.

Sedangkan di madrasah, Pengawas Pendidikan Agama Islam melakukan penilaian. Maksud penilaian dalam kontek ini didefinisikan sebagai: penentuan derajat kualitas berdasarkan kriteria yang ditetapkan terhadap pelaksanaan pendidikan agama islam di sekolah umum dan penyelenggaraan pendidikan di madrasah termasuk madrasah salafiyah dan pembinaan. Maksud pembinaan adalah kegiatan yang dilakukan oleh pengawas pendidikan agama islam dalam memberikan arahan, bimbingan, contoh dan saran dalam pelaksanaan pendidikan agama islam di sekolah umum dan penyelenggaraan pendidikan di madrasah secara menyeluruh baik teknis pendidikan maupun administrasi.

\footnotetext{
${ }^{38}$ Peraturan Menteri Agama Republik Indonesia Nomor 16 Tahun 2010 Tentang Pengelolaan Pendidikan Agama pada Sekolah (Cet. I; Jakarta: Sinar Grafika, 2010), h. 11.

${ }^{39}$ Peraturan Menteri Agama RI Nomor 2 Tahun 2012 tentang Pengawas Madrasah dan Pengawas Pendidikan Agama Islam di Sekolah (Cet. I; Bandung: PT. Citra Umbaran, 2012), h. 3.

${ }^{40}$ Departemen Agama RI, Profesionalitas Pelaksanaan Pengawasan Pendidikan (Jakarta: DIRJEND Kelembagaan Agama Islam, 2005), h. 79.
} 
Tugas pokok pengawas sekolah adalah melakukan penilaian dan pembinaan dengan melaksanakan fungsi-fungsi supervisi, baik supervisi akademik maupun supervisi manajerial yaitu:

a. Tugas pengawas sekolah yaitu membantu kepala sekolah dalam menyesuaikan program pendidikan dari waktu kewaktu secara berkesinambungan (dalam rangka menghadapi tantangan perubahan jaman)

b. Tugas pengawas sekolah yaitu bekerjasama mengembangkan proses pembelajaran yang tepat, efektif dan efesien

c. Tugas pengawas sekolah yaitu membina guru agar dapat mendidik para peserta didik dengan baik atau menegakkan disiplin kerja secara manusiawi. ${ }^{41}$

Tugas pengawas sekolah pada dasarnya bertugas memberikan pembinaan, penilaian dan bantuan/ bimbingan mulai dari penyusunan rencana program sekolah berbasis data sekolah, proses pelaksanaan program berdasarkan sasaran, sampai dengan penilaian program dan hasil yang ditargetkan. Bantuan ini diberikan pengawas sekolah kepada kepala sekolah dan seluruh staf sekolah dalam pengelolaan sekolah atau penyelenggaraan pendidikan di sekolah untuk meningkatkan kualitas kinerja sekolah. ${ }^{42}$

Adapun tugas monitoring/pemantauan pada aspek manajerial pengawas pendidikan, sebagaimana tertuang dalam matrik tugas pokok pengawas meliputi: memantau penjaminan/standar mutu pendidikan, memantau proses penerimaan peserta didik baru, memantau pelaksanaan ujian, memantau proses dan hasil belajar peserta didik dan lain-lain. Tugas ini dilakukan melalui pengamatan langsung ataupun menganalisis dokumen yang berkaitan dengan penyelenggaraan pendidikan di sekolah. Setelah diperoleh data dan informasi yang diperlukan, selanjutnya pengawas sekolah melakukan analisis komprehensif hasil penilaian dan hasilnya sebagai bahan untuk melakukan inovasi pendidikan di sekolah binaan. ${ }^{43}$ Atas dasar penilaian tersebut pengawas sekolah melakukan pembinaan dan pemecahan masalah sesuai kasus dan permasalahan yang terungkap dalam data dan informasi yang telah diperolehnya.

Sahertian mengemukakan, pengawas sekolah bertugas memberikan layanan dan bantuan untuk mengembangkan situasi pembelajaran yang dilakukan oleh guru di kelas. Pendapat ini sesuai dengan apa yang dikemukakan Olive dalam Piet A. Sahertian bahwa sasaran pengawas sekolah ialah, (a) mengembangkan kurikulum yang sedang dilaksanakan di sekolah, (b) meningkatkan proses pembelajaran di sekolah, (c) mengembangkan seluruh staf di sekolah. ${ }^{44}$

Sedangkan Harris mencatat sembilan tugas pokok pengawas pendidikan sebagai berikut:

a. Melakukan pengembangan kurikulum

b. Melakukan pengorganisasian pengajaran

c. Menyediakan fasilitas

d. Penyediaan material

\footnotetext{
${ }^{41}$ Mustafa Husba, Strategi Membangun Kinerja Supervisor Pendidikan, h. 39.

${ }^{42}$ Syaiful Sagala, Supervisi Pembelajaran dalam Profesi Pendidikan; Membantu Mengatasi Kesulitan Guru Memberikan Layanan Belajar yang Bermutu (Cet. II; Bandung: CV. Alfabeta, 2010), h. 155.

${ }^{43}$ Syaiful Sagala, Supervisi Pembelajaran dalam Profesi Pendidikan, h. 156

${ }^{44}$ Piet A. Sahertian, Konsep Dasar dan Teknik Supervisor Pendidikan dalam Rangka Pengembangan Sumber Daya Manusia, h. 21.
} 
e. Pengaturan pendidikan in service

f. Orientasi anggota staff

g. Berhubungan dengan pelayanan peserta didik tertentu

h. Pengembangan public relation

i. Evaluasi pelaksanaan supervisi. ${ }^{45}$

Pengawas sekolah yang melaksanakan tugas dan fungsinya dengan baik terutama fungsi pembinaan guru dapat meningkatkan dedikasi, motivasi guru dalam mengemban tugas mencerdaskan kehidupan bangsa sebagai perwujudan dan tujuan pendidikan nasional dan tujuan nasional. ${ }^{46}$ Optimalisasi pelaksanaan tugas pengawas dapat terwujud bila pengawas sekolah memiliki kompetensi, dedikasi, dan motivasi yang tentunya diwujudkan dalam suatu kinerja yang baik.

Dapat ditegaskan tentang tugas pengawas sekolah melakukan pembinaan, penilaian dan bantuan atau bimbingan mulai dari penyusunan rencana program sekolah berbasis data sekolah, proses pelaksanaan program berdasarkan sasaran, sampai dengan penilaian program dan hasil yang ditargetkan untuk mencapai tujuan sekolah sesuai prinsip otonomi dan implementasi manajemen berbasis sekolah. Pelaksanaan tugas pengawas pendidikan sebagai salah satu fungsi manajemen pendidikan yang sangat penting dalam mewujudkan penyelenggaraan pendidikan dalam kerangka pendidikan nasional.

\section{Peran Pengawas Pendidikan}

Peran pengawas pendidikan sebagai berikut:

a. Berperan sebagai nara sumber bagi guru dalam merencanakan dan melaksanakan tugas-tugasnya, serta dalam mendiagnosa keberhasilan, sehingga guru dapar secara terus menerus meningkatkan kinerjanya.

b. Berperan sebagai fasilitator dan bahkan pembimbing yang membantu guru dalam mengatasi hambatan yang dihadapi maupun dalam mengatasi kekurangan yang dialami.

c. Berperan sebagai motivator yang dengan berbagai cara selalu mengupayakan agar guru mau bekerja lebih bersungguh-sungguh dan bersemangat. Termasuk di sini memberikan tekanan dan dukungan agar guru mencapai hasil pengajarannya.

d. Berperan sebagai aparat pengendali mutu pengajaran yang secara periodik dan sistematik mengecek, menganalisis, mengevaluasi dan mengarahkan serta mengambil tindakan agar strategi peningkatan efektifitas pengajaran dapat terlaksana dengan baik dan berhaasil.

e. Berperan sebagai seorang assessor bagi kepentingan program akreditasi sekolah. ${ }^{47}$

Dalam penjelasan lain dikatakan bahwa peran pengawas pendidikan dalam melaksanakan supervisi akademik yaitu:

a. Berperan sebagai patner (mitra) guru dalam meningkatkan mutu proses dan hasil pembelajaran dan bimbingan di sekolah/ madrasah binaannya;

\footnotetext{
${ }^{45}$ Harris, Ben M. dan Benssent, Supervisory Behavior in Education (Second Edition, Prentice, Inc: Englewood Cliffs: New Jersey, 2001), h. 21.

${ }^{46}$ Piet A. Sahertian, Konsep Dasar dan Teknik Supervisor Pendidikan dalam Rangka Pengembangan Sumber Daya Manusia, h. 6.

${ }^{47}$ Yususf A. Hasan (dkk), Pedoman Pengawasan Untuk Madrasah dan Sekolah Umum (Cet. I; Jakarta: CV. Mekar Jaya, 2002), h. 6-7
} 
b. Berperan sebagai inovator dan pelopor dalam mengembangkan inovasi pembelajaran dan bimbingan di sekolah/madrasah binaannya;

c. Berperan sebagai konsultan pendidikan dan pembelajaran di sekolah/ madrasah binaannya;

d. Berperan sebagai konselor bagi guru dan seluruh tenaga kependidikan di sekolah/ madrasah

e. Berperan sebagai motivator untuk meningkatkan kinerja guru dan semua tenaga kependidikan di sekolah/ madrasah. ${ }^{48}$

Dalam melaksanakan supervisi manajerial, pengawas sekolah/madrasah memiliki peranan khusus sebagai:

a. Konseptor yaitu menguasai metode, teknik dan prinsip-prinsip supervisi dalam rangka meningkatkan mutu pendidikan di sekolah/ madrasah;

b. Programer yaitu menyusun program kepengawasan berdasarkan visi, misi, tujuan dan program pendidikan di sekolah/madrasah;

c. Komposer yaitu menyusun metode kerja dan instrumen kepengawasan yang diperlukan untuk melaksanakan tugas pokok dan fungsi pengawas di sekolah/ madrasah;

d. Reporter yaitu melaporkan hasil-hasil pengawasan dan menindak lanjutinya untuk perbaikan program pengawasan berikutnya di sekolah/madrasah;

e. Builder yaitu: membina kepala sekolah/madrasah dalam pengelolaan (manajemen) dan administrasi sekolah/madrasah berdasarkan manajemen peningkatan mutu pendidikan di sekolah/madrasah; dan membina guru dan kepala sekolah/ madrasah dalam pelaksanaan bimbingan konseling di sekolah/madrasah.

f. Supporter yaitu mendorong guru dan kepala sekolah/madrasah dalam merefleksikan hasil-hasil yang dicapai untuk menemukan kelebihan dan kekurangan dalam melaksanakan tugas pokoknya di sekolah/madrasah;

g. Observer yaitu memantau pelaksanaan standar nasional pendidikan di sekolah/ madrasah;

h. User yaitu memanfaatkan hasil-hasil pemantauan membantu kepala sekolah dalam menyiapkan akreditasi sekolah. ${ }^{49}$

Peran pengawas sangat membantu memperbaiki dan meningkatkan pengolahan madrasah sehingga tercipta kondisi kegiatan pembelajaran yang efektif. Pengawas yang melaksanakan pengawasan sekolah yang efektif dapat memperbaiki profesional guru di madrasah.

\section{METODOLOGI PENELITIAN}

Penelitian ini adalah penelitian kualitatif dengan lokasi di Madrasah Aliyah Kabupaten Sigi Propinsi Sulawesi Tengah. Pendekatan yang digunakan adalah pendekatan teologis normatif dan yuridis formal. Sumber data primer adalah data yang berasal dari pengawas, guru Mata Pelajaran Pendidikan Agama Islam, kepala madrasah, dan peserta didik. Data dikumpulkan dengan metode observasi, wawancara, dan dokumentasi dengan instrumen panduan observasi, acuan dokumentasi dan pedoman wawancara. Data diolah dan dianalisis dengan analisis deduktif, komparatif

\footnotetext{
${ }^{48}$ Nana Sudjana, Standar Mutu Pengawas (Cet. II; Jakarta: Gaung Persada Press, 2007), h. 3.

${ }^{49}$ Surya Darma; Direktur Tenaga Kependidikan, Peran dan Fungsi Pengawas Sekolah/Madrasah (Dalam Jurnal Tenaga Kependidikan Vol. 3, No. 1, April 2008)
} 
dan verifikasi data. Data diuji keabsahannya dengan presistent observation dan uji tringgulasi.

\section{HASIL PENELITIAN DAN PEMBAHASAN}

Pelaksanaan supervisi akademik pada Madrasah Aliyah Kabupaten Sigi secara keseluruhan informasi diperoleh berdasarkan hasil wawancara, observasi, dan studi dokumentasi terhadap informan utama dan informan penunjang kemudian dianalisis sehingga dapat ditetapkan suatu kesimpulan.

Peneliti melakukan wawancara dan observasi kepada kepala madrasah, wakil kepala madrasah, guru, dan peserta didik yang ada pada Madrasah Aliyah Kabupaten Sigi, berdasarkan indikator supervisi akademik yakni merencanakan supervisi akademik, melaksanakan supervisi individu, dan melaksanakan kelompok, sebagai berikut:

\section{Merencanakan Supervisi Akademik}

Pelaksanaan supervisi akademik dilakukan oleh pengawas. Secara keseluruhan informasi diperoleh berdasarkan hasil wawancara, observasi, dan studi dokumentasi terhadap informan utama dan informan penunjang kemudian dianalisis sehingga dapat ditetapkan suatu kesimpulan.

Peneliti melakukan wawancara dan observasi kepada pengawas, kepala madrasah, wakil kepala madrasah, guru, dan peserta didik yang ada pada Madrasah Aliyah Kabupaten Sigi. Untuk lebih jelasnya upaya mengembangkan profesional Guru Mata Pelajaran Pendidikan Agama Islam melalui perencanaan supervisi akademik, sebagai berikut:

Perencanaan kegiatan supervisi oleh pengawas merupakan suatu rencana kegiatan yang tersusun secara sistematis, berfungsi untuk mengarahkan seluruh kegiatan supervisi akdemik agar tujuan supervisi akademik dapat tercapai dengan maksimal.

Perencanaan pelaksanaan supervisi akademik pada Madrasah Aliyah Kabupaten Sigi dilakukan langkah-langkah, sebagai berikut:

a. Menentukan Tujuan

Peneliti melakukan wawancara dengan pengawas Madrasah Aliyah Kabupaten Sigi sebagai berikut:

Perencanaan supervisi ditentukan tujuan yang merupakan arah pelaksanaan kegiatan agar dalam pelaksanaannya tidak simpang siur karena tujuan ini merupakan pengarah bagi supervisor dalam penentuan kegiatan-kegiatan berikutnya. Adapun tujuan supervisi untuk membantu mengembangkan profesional Guru Mata Pelajaran Pendidikan Agama Islam dalam hal ini membantu agar guru mampu menyusun program tahunan dan semester; (2) membantu agar guru mampu melaksanakan penyusunan model satuan pembelajaran; (3) membantu agar guru mampu menentukan norma kenaikan kelas; (4) membantu agar guru mampu menentukan norma penilaian; (5) membantu agar guru mampu melaksanakan evaluasi belajar; (6) membantu agar guru mampu meningkatkan perbaikan mengajar; dan (7) membantu agar guru mampu mengat ur disiplin dan tata tertib kelas. ${ }^{50}$

Selanjutnya peneliti mengadakan tela'ah dokumentasi yang ada Madrasah

\footnotetext{
${ }^{50}$ Usman, Pengawas Pendidikan Agama Islam, Madrasah Aliyah Kabupaten Sigi, Wawancara.
} 
Aliyah Kabupaten Sigi. Berdasarkan hasil studi dokumentasi berupa buku notulen rapat dan buku program kerja madrasah yang ada. Menunjukkan bahwa supervisor telah menetapkan tujuan pelaksanaan supervisi akademik. Hal ini terlihat bahwa dalam buku notulen rapat tertera perencanaan supervisi akademik dengan menuliskan tujuan yang akan dicapai pada kegiatan supervisi tersebut.

Berdasarkan pemaparan di atas dijelaskan bahwa dalam perencanaan supervisi akademik pada Madrasah Aliyah Kabupaten Sigi mencantumkan tujuan yang merupakan arah bagi pelaksanaan supervisi akademik agar dapat menghasilkan sesuai dengan yang telah ditentukan.

Peneliti melakukan wawancara terhadap beberapa orang guru sebagai informan. Berikut ini kutipan hasil wawancara dengan informan sebagai berikut.

Selanjutnya guru di Madrasah Aliyah Al-Muhibba Soulowe Kabupaten Sigi, menyatakan:

Yang melakukan supervisi akademik di madrasah ini yaitu pengawas. Berkaitan dengan penentuaan tujuan biasanya sebelum supervisor menetapkan tujuan terlebih dahulu supervisor selalu melakukan konsultasi kepada dewan guru agar tujuan tersebut dapat mewakili semua masalah yang telah diidentifikasi agar dapat membawa manfaat bagi perbaikan proses pembelajaran kedepan, yang muaranya adalah upaya mengembangkan profesional Guru Mata Pelajaran Pendidikan Agama Islam. ${ }^{51}$

Berdasarkan pemaparan dari informasi pendukung di atas tercermin bahwa supervisor dalam menetapkan tujuan diperencanaan terlebih dahulu melakukan diskusi terhadap guru agar tujuan yang ditetapkan dapat mewakili masalah-masalah yang dihadapi oleh guru yang bersangkutan sehingga dapat memberikan manfaat dan perbaikan terhadap pengembangan profesional Guru Mata Pelajaran Pendidikan Agama Islam pada Madrasah Aliyah Kabupaten Sigi.

Hasil wawancara dengan guru pada Madrasah Aliyah Al-Khairaat Pakuli Kabupaten Sigi menyatakan bahwa:

Penetapan tujuan oleh supervisor berdasarkan kepada identifikasi masalah yang telah lalu yang dihadapi oleh guru dalam pelaksanaan pembelajaran sehingga masalah tersebut dapat diatasi dengan metode-metode tertentu karena telah merupakan dasar dalam penyusunan tujuan supervisi berikutnya. Saya katakan demikian karena pengawas madrasah selalu mengkonsultasikan perencanaan supervisi yang akan ditetapkan. ${ }^{52}$

Berdasarkan hasil wawancara dengan beberapa kepala madrasah dan guru, maka perumusan tujuan supervisi akademik telah baik karena berdasarkan atas identifikasi masalah yang dihadapi oleh para guru yang perlu dicarikan solusi untuk keluar dari permasalahan tersebut, dengan melibatkan guru untuk memberikan masukan dan penilaian terhadap perumusan tujuan sebelum supervisor memutuskan tujuan supervisi.

Selanjutnya peneliti melakukan wawancara terhadap guru pada Madrasah Aliyah Al-Khairaat Sibalaya Kabupaten Sigi, Berdasarkan hasil wawancara terhadap guru sebagai berikut:

\footnotetext{
${ }^{51}$ Fildan Ahmad, Guru Akidah Akhlak, Madrasah Aliyah Al-Muhibba Soulowe Kabupaten Sigi, Wawancara.

${ }^{52}$ Darmawati, Guru Fikih, Madrasah Aliyah Al-Khairaat Pakuli Kabupaten Sigi, Wawancara.
} 
Pengawas madrasah merumuskan tujuan dalam perencanaan supervisi. Jika diperhatikan dengan seksama pengawas madrasah dalam merumuskan tujuan telah berpedoman terhadap identifikasi masalah guru sehingga tujuan yang dirumuskan lebih mengarah pada permasahan-permasalahan yang perlu menjadi fokus perhatian dalam supervisi. ${ }^{53}$

Berdasarkan hasil wawancara dengan kepala madrasah dan para guru di atas, maka peneliti berpendapat bahwa pengawas madrasah sebelum melakukan supervisi di kelas, terlebih dahulu menentukan tujuan dalam perencanaan supervisi yaitu untuk mengetahui letak yang harus diperbaiki terhadap apa yang harus dilakukan oleh guru dalam pembelajaran dan kemudian memberikan pelayanan kepada guru yang mengalami kesulitan dalam pelaksanaan tugasnya di kelas, yang tentu mengarah pada pengembangan profesional Guru Mata Pelajaran Pendidikan Agama Islam pada Madrasah Aliyah Kabupaten Sigi.

Selanjutnya, peneliti melakukan observasi melalui member chek terhadap informan tentang keakuratan data yang diperoleh, dan data yang diperoleh peneliti sehingga penulis berpendapat bahwa pengawas madrasah telah menetapkan tujuan supervisi dalam perencanaan dengan tujuan untuk mengetahui kegiatan yang dilakukan oleh guru dalam melaksanakan proses pembelajaran dan sekaligus melakukan perbaikan dan pembinaan terhadap guru yang mengalami kesulitan dalam proses pembelajaran di kelas agar tercapai pengembangan profesional Guru Mata Pelajaran Pendidikan Agama Islam pada Madrasah Aliyah Kabupaten Sigi.

Berdasarkan hasil wawancara, data observasi, dan tela'ah dokumentasi maka dapat dipahami bahwa tujuan dari kegiatan supervisi akademik yang ditentukan oleh pengawas yaitu pertama agar terjadi prosespembelajaran yang mengikuti prinsip belajar tuntas tanpa harus mengorbankan pencapaian target kurikulum yang ada; kedua agar terjadi peningkatan semangat guru dalam mengajar dan minat peserta didik dalam mempelajari mata pelajaran yang diajarkan. Ketiga agar terwujud suatu suasana sadar dan peduli mutu di madrasah, khususnya di kalangan guru, peserta didik, dan kepala madrasah, dalam arti semua pihak tersebut bertekad (commited) untuk mewujudkan misi yang sama yaitu tingkat penguasaan peserta didik yang tinggi atas materi pelajaran yang diajarkan.

b. Menentukan Aspek-aspek yang Akan Disupervisi

Pengawas sebelum melakukan supervisi akademik terlebih dahulu menentukan aspek-aspek yang akan disupervisi, untuk mendapatkan gambaran kegiatan yang akan dilakukan dalam kegiatan supervisi. Berdasarkan hasil wawancara peneliti dengan pengawas madrasah tentang penentuan aspek-aspek yang akan disupervisi pada kegiatan supervise. Perencanaan pelaksanaan supervisi akademik kepada guru Pendidikan Agama Islam pada Madrasah Aliyah Kabupaten Sigi.

Peneliti mewawancarai pengawas pada Madrasah Aliyah Kabupaten Sigi sebagai berikut:

Tentu dalam instrument supervisi dicantumkan aspek-aspek yang akan disupervisi seperti di antaranya apakah guru menyiapkan program perencanaan proses pembelajaran, apakah guru menyusun silabus? Juga aspek terpenting yaitu memeriksa identitas mata pelajaran atau tema pelajaran, standar

\footnotetext{
${ }^{53}$ Kamaruddin, Guru Akidah Akhlak Madrasah Aliyah Al-Khairaat Sibalaya Kabupaten Sigi, Wawancara.
} 
kompetensi, kompetensi dasar, materi pembelajaran, kegiatan pembelajaran, indikator pencapaian kompetensi, penilaian, alokasi waktu, dan sumber belajar. $^{54}$

Peneliti melanjutkan wawancara dengan kepala Madrasah Aliyah Al-Khairaat Sibalaya Kabupaten Sigi sebagai berikut:

Supervisi akademik dilaksanakan mulai dari perencanaan supervisi dan menyiapkan istrumen supervisi, yaa.. dalam instrument itu dicantumkan aspek yang akan disupervisi seperti materi ajar, alokasi waktu, metode pembelajaran, kegiatan pembelajaran pendahuluan, kegiatan inti, kegiatan penutup, penilaian hasil belajar, sumber belajar, dan pengawasan proses pembelajaran yang dilakukan oleh guru. ${ }^{55}$

Hasil wawancara peneliti dengan pengawas pendidikan Madrasah Aliyah Kabupaten Sigi, sebagai berikut:

Dalam perencanaan supervisi harus ada aspek-aspek yang akan disupervisi untuk guru agar dalam supervisi terarah dengan baik, dan semua itu dicantumkan dalam instrument supervisi. Adapun aspek-aspek dalam supervisi adalah persiapan mengajarnya seperti program tahunan, program semester, silabus, dan RPP. Kemudian pelaksanaannya di kelas seperti kegiatan awal, kegiatan inti yang dilengkapi dengan penggunaan alat peraga, penerapan metode, dan kemudian kegiatan penutup, misalnya pemberian nilai kepada peserta didik. ${ }^{56}$

Selanjutnya peneliti mewawancarai kepala Madrasah Aliyah DDI Lonja Kabupaten Sigi. Hasil wawancara sebagai berikut:

Dalam perencanaan supervisi dicantumkan aspek-aspek yang akan disupervisi. Adapun aspek-aspek yang akan disupervisi secara rinci tertera dalam lembar supervisi (instrument supervisi) yaitu perangkat pembelajaran yang dibuat oleh guru seperti program tahunan, program semester, silabus, RPP dan pengembangan materi, buku nilai, kegiatan pembelajaran seperti kegiatan pendahuluan, alat dan media pembelajaran, motivasi apersepsi, kejelasan kompetensi dasar dan kesiapan bahan ajar. Kegiatan inti: penguasaan materi, pengelolaan kelas, pengelolaan waktu, metode/pendekatan, strategi yang bervariasi, penggunaan alat bantu pembelajaran, peranan guru sebagai fasilitator, teknik bertanya, penggunaan white board, interaksi guru dengan peserta didik. Kegiatan menutup pelajaran: membuat rangkuman, menggunakan alat pembelajaran dan memberikan tugas lanjutan. ${ }^{57}$

\footnotetext{
${ }^{54}$ Wahab Badry, Pengawas Pendidikan Agama Islam, Madrasah Aliyah Kabupaten Sigi, Wawancara.

${ }^{55}$ Taif Talib, Kepala Madrasah Aliyah Al-Khairaat Sibalaya Kabupaten Sigi, Wawancara. Wawancara.

${ }^{56}$ Muhazzab, Pengawas Pendidikan Agama Islam, Madrasah Aliyah Kabupaten Sigi,

${ }^{57}$ Agustina, Kepala Madrasah Aliyah DDI Lonja Kabupaten Sigi, Wawancara.
} 
Selanjutnya peneliti melakukan wawancara dengan kepala Madrasah Aliyah AlKhairaat Pulu Dolo Kabupaten Sigi, agar data yang diperoleh lebih meyakinkan, berikut ini petikan hasil wawancaranya sebagai berikut:

Di dalam program perencanaan supervisi, aspek-aspek yang akan disupervisi adalah kelengkapan administrasi kelas seperti program tahunan, program semester, silabus, RPP dan pengembangan materi sedangkan pelaksanaannya adalah mulai dari kegiatan awal, kegiatan inti dan penilaian hasil belajar peserta didik. Dalam hal ini yang berkaitan langsung dengan persiapan dan pelaksanaan pembelajaran di kelas. ${ }^{58}$

Selanjutnya penulis melakukan wawancara kepada guru pada Madrasah Aliyah Al-Khairaat Pulu Dolo Kabupaten Sigi untuk memperkuat hasil wawancara dari pengawas madrasah. Hasil wawancara sebagai berikut:

Biasanya dikomunikasikan kepada guru tentang aspek-aspek yang akan disupervisi dalam lembar supervisi yang akan dipakai dalam supervisi sehingga guru memahami semua yang tertera dalam lembar supervisi. Aspek-aspek pokok yang dicantumkan dalam perencanaan supervisi yaitu: (1) Masalah wawasan dan kemampuan profesional guru; (2) Masalah kehadiran dan aktivitas guru; (3) Masalah persiapan mengajar guru, mulai dari penyusunan analisis materi pelajaran, program tahunan, program catur wulan, program satuan pelajaran sampai dengan persiapan mengajar harian atau rencana pengajaran; (4) Masalah pencapaian target kurikuler dan kegiatan ekstrakurikuler; (5) Masalah kerja sama guru dengan peserta didik, dengan semua guru; (6) Masalah kemajuan belajar peserta didik; (7) Masalah sarana dan prasarana pendidikan; (8) Masalah metodologi pendidikan dan pengajaran. ${ }^{59}$

Selanjutnya penulis melakukan wawancara kepada guru pada Madrasah Aliyah Wumbulangi Kabupaten Sigi untuk memperkuat hasil wawancara dengan pengawas, kepala madrasah dan guru di atas. Hasil wawancara sebagai berikut:

Aspek-aspek yang telah ditetapkan dalam supervisi akademik biasanya pengawas memeriksa, menelaah, dan mengevaluasi tentang pengelolaan pembelajaran yang meliputi apakah guru menguasai materi pembelajaran, apakah guru memberi contoh/ilustrasi/analogi, apakah guru menggunakan sumber, alat, media pembelajaran, apakah guru mengarahkan peserta didik untuk aktif berpartisipasi, apakah guru memberi penguatan, apakah guru melaksanakan kegiatan pembelajaran dengan urutan yang logis/teratur, apakah guru merespon secara positif keingintahuan peserta didik, dan apakah guru menunjukkan ant usiasme/gairah mengajar. ${ }^{60}$

Berdasarkan hasil wawancara terhadap informan di atas, maka peneliti dapat memaparkan bahwa pengawas sebagai supervisor menetapkan aspek yang akan

\footnotetext{
${ }^{58}$ Asma, Kepala Madrasah Aliyah Al-Khairaat Pulu Dolo Kabupaten Sigi, Wawancara.

${ }^{59}$ Rajamuddin, Guru Fikih, Madrasah Aliyah Al-Khairaat Pulu Dolo Kabupaten Sigi, Wawancara.

${ }^{60}$ Farhana Azzahra, Guru Al-Qur'an Hadis, Madrasah Aliyah WumbulangiKabupaten Sigi.
} 
disupervisi. Selanjutnya peneliti melakukan wawancara dengan guru pada Madrasah Aliyah al-Khairaat Kabeloa Pewunu Kabupaten Sigi agar data yang diperoleh lebih meyakinkan, sebagaimana pemaparan sumber data berikut ini.

Aspek-aspek yang tertera dalam perencanaan supervisi telah disampaikan oleh pengawas madrasah sehingga dalam pelaksanaan supervisi kali ini keseluruhan dari aspek yang dimaksud telah diamati dan diperiksa oleh pengawas madrasah terhadap persiapan guru untuk mencapai sasaran supervisi terutama dalam pengembangan profesional Guru Mata Pelajaran Pendidikan Agama Islam pada madrasah ini. ${ }^{61}$

Berdasarkan hasil wawancara terhadap informan di atas, maka peneliti dapat memaparkan bahwa pengawas telah menetapkan aspek-aspek yang akan disupervisi. Hal ini terbukti dari hasil wawancara menunjukkan bahwa pengawas telah menyampaikan aspek-aspek supervisi sesuai dengan lembar pengamatan supervisi yang akan digunakan dalam penilaian supervisi.

Selanjutnya peneliti mengadakan studi dokumentasi terhadap dokumen perencanaan supervisi berupa lembar observasi supervisi yang disediakan oleh pengwas Madrasah Aliyah Kabupaten Sigi, menunjukkan bahwa aspek-aspek yang akan disupervisi telah ditentukan dalam lembar supervisi yang sebelumnya telah dibagikan kepada semua guru sebelum disupervisi berupa format supervisi pendidikan.

Berdasarkan pemaparan hasil uji trianggulasi dengan mengecek secara berulang, mencocokkan dan membandingkan data dari berbagai sumber, baik wawancara secara mendalam, observasi secara kontinyu, dan analisis dokumentasi ditegaskan bahwa dalam upaya merencanakan supervisi ditentukan aspek-aspek yang akan disupervisi melalui persiapan instrument penelitian seperti yang tertera di atas, terutama dalam administrasinya di kelas yang merupakan persiapan-persiapan guru dalam melaksanakan pembelajaran.

c. Menentukan Teknik-teknik Supervisi Akademik yang Akan Diterapkan

Penentuan teknik yang digunakan oleh supervisor adalah hal yang penting dalam kegiatan supervisi akademik, karena teknik yang digunakan adalah yang tepat dengan tujuan yang ingin dicapai serta aspek yang akan disupervisi. Berikut ini adalah petikan wawancara peneliti dengan beberapa informan.

Informan mengatakan dalam wawancara bahwa:

Dalam pelaksanaan supervisi, teknik yang digunakan adalah yang tepat dengan pencapaian tujuan dan kesesuaian dengan aspek yang disupervisi dan yang digunakan adalah pengamatan terhadap administrasi guru dan observasi terhadap pembelajaran di kelas dimana supervisor mengamati guru mulai dari kegiatan pembuka sampai dengan kegiatan penutup, kemudian dilanjutkan dengan wawancara dengan guru yang bersangkutan. ${ }^{62}$

Berdasarkan pemaparan data di atas, diperoleh gambaran, bahwa supervisor mengupayakan teknik yang digunakan disesuaikan dengan tujuan dan aspek yang disupervisi. Ini dimaksudkan agar dalam pencapaian tujuan dapat lebih terarah. Berikut kutipan hasil wawancara dengan sumber data

Supervisor dalam merencanakan supervisi memilih dan menetapkan teknik

\footnotetext{
${ }^{61}$ Ismail Syam, Guru Akidah Akhlak, Madrasah Aliyah al-Khairaat Kabeloa Pewunu Kabupaten Sigi, Wawancara.

${ }^{62}$ Fitriani, Kepala Madrasah Aliyah, al-Khairaat Kabeloa Pewunu Kabupaten Sigi, Wawancara.
} 
supervisi yang dirumuskan serta kesesuaian dengan aspek yang akan disupervisi sehingga merupakan rangkaian kegiatan yang saling mendukung antara satu dengan yang Iainnya. Misalnya dimasukkan teknik, observasi kelas, pertemuan individual dan kelompok, dan demonstrasi mengajar. ${ }^{63}$

Supervisor dalam menjalankan supervisi akadmeik selalu disesuaikan berdasarkan kebutuhan guru baik dalam perencanaan pembelajaran maupun dalam pelaksanaan pembelajaran. Supervisor dalam memilih teknik tetap mengacu pada kesulitan-kesulitan guru yang dihadapi sebelumnya yang kemudian dirumuskan dalam bentuk tujuan dan tetap disesuaikan dengan aspek yang akan disupervisi agar tidak saling tumpang tindih akan tetapi merupakan satu kesatuan yang saling mendukung.

Berdasarkan hasil wawancara di atas menunjukkan bahwa dalam menentukan teknik supervisi dalam perencanaan supervisor tetap mengacu pada perumusan tujuan dan kesesuaian dengan aspek yang disupervisi agar saling menunjang dalam pencapaian tujuan.

Selanjutnya peneliti melakukan studi dokumentasi kepada informan dalam waktu yang berbeda. Hasil studi dokumentasi menunjukkan bahwa penentuan teknik sudah tepat dengan memperhatikan tujuan dan aspek yang akan disupervisi dan sesuai dengan indicator teknik supervisi.

Peneliti dapat menegaskan, bahwa penetapan teknik yang tertera dalam perencanaan yang ditetapkan oleh supervisor dalam kegiatan supervisi telah disusun berdasarkan tujuan dan aspek yang akan disupervisi sehingga pelaksanaannya bermuara pada pengembangan profesional Guru Mata Pelajaran Pendidikan Agama Islam Madrasah Aliyah Kabupaten Sigi.

Berdasarkan penjelasan dari beberapa indikator perencanaan supervisi kepala madrasah di atas, maka dapat ditegaskan bahwa penyusunan perencanaan supervisi akademik pada Madrasah Aliyah Kabupaten Sigi sudah baik karena telah mencakup beberapa aspek yang merupakan isi dari kegiatan supervisi dan tujuan merupakan arah pelaksanaan supervisi, sehingga dapat menjadi acuan dalam melihat keberhasilan supervisi sehingga pengembangan prodesionalisme guru tercapai secara optimal.

\section{Melaksanakan Supervisi Akademik Secara Individu}

Pertemuan individual dilaksanakan oleh pengawas Madrasah Aliyah Kabupaten Sigi untuk mengembangkan profesionalisme guru, memberi pemecahan kesulitan yang dihadapi, sehingga dapat melaksanakan proses pembelajaran lebih baik, serta dapat memperbaiki kelemahan dan kekurangan yang dimiliki guru pada Madrasah Aliyah Kabupaten Sigi.

Peneliti melakukan wawancara dengan pengawas pendidikan pada Madrasah Aliyah Kabupaten Sigi sebagai berikut:

Penekanan saya setiap bertemu dengan guru adalah supaya selalu mengikuti perkembangan yang ada, baik di bidang teknologi, ilmu pengetahuan terutama pengetahuan yang mereka ajarkan dengan menganjurkan membaca, mengikuti diskusi/seminar dan sebagainya agar guru mengalami peningkatan wawasan dan profesionalisme guru. Demikian pula masalah kerja sama guru baik terhadap peserta didik, sesama guru, antara guru dengan staf, termasuk mengenai

\footnotetext{
${ }^{63}$ Asma, Kepala Madrasah Aliyah Al-Khairaat Pulu Dolo Kabupaten Sigi, Wawancara.
} 
kedisiplinan terutama kehadiran guru. Yang terbanyak frekuensi penekanan saya adalah mengenai penggunaan RPP dan pencapaian target kurikulum. ${ }^{64}$

Dalam percakapan individual ini pengawas pendidikan pada Madrasah Aliyah Kabupaten Sigi berusaha mengembangkan profesionalisme guru, mendorong guru mengatasi kesulitan dan memberikan pengarahan, hal-hal yang masih meragukan sehingga terjadi kesepakatan konsep tentang situasi pembelajaran yang sedang dihadapi.

Peneliti melakukan wawancara dengan guru Fiqih pada Madrasah Aliyah AlKhairaat Pakuli Kabupaten Sigi, sebagai berikut:

Pelaksanaan supervisi yang dilakukan oleh pengawas madrasah yang berkaitan dengan pertemuan individu menurut saya pengawas madrasah melaksanakan pertemuan individu dengan guru, biasanya pertemuan individu ini laksanakan jika ada permasalahan yang dihadapi oleh guru, tetapi hanya sekali-sekali saja, termasuk permasalahan yang berkaitan dengan penyusunan RPP, dan penerapan metode pembelajaran. ${ }^{65}$

Berdasarkan hasil wawancara ditegaskan bahwa pengawas Madrasah Aliyah Kabupaten Sigi telah melaksanakan supervisi berkaitan dengan pertemuan individu. Pengawas pendidikan yang bertugas pada Madrasah Aliyah Kabupaten Sigi lebih intensif melakukan percakapan individual yang dilaksanakan di ruang kepala madrasah jika ada permasalahan yang dihadapi guru.

Pelaksanaan supervisi akademik melalui pertemuan individu yang dilakukan pengawas Madrasah Aliyah Kabupaten Sigi merupakan salah satu upaya dalam mengembangkan pofesionalisme guru. Dalam hal ini supervisor fokusnya adalah mengkaji, menilai, memperbaiki, meningkatkan, dan mengembangkan mutu kegiatan pembelajaran yang dilakukan oleh perorangan atau kelompok melalui bimbingan dan konsultasi dialog profesional, agar guru bekerja secara profesional bilamana memiliki kemampuan kerja yang tinggi dan kesungguhan hati untuk mengerjakan tugas guru dengan sebaik-baiknya.

Pertemuan individu dilakukan oleh pengawas dalam rangka mengembangkan profesionalisme guru sebagai kontrol agar kegiatan pembelajaran pada Madrasah Aliyah Kabupaten Sigi terarah pada tujuan yang telah ditetapkan. Pembimbingan dan pengawasan yang dilakukan pengawas terhadap guru Pendidikan Agama Islam pada Madrasah Aliyah Kabupaten Sigi dalam rangkan mengembangkan profesionalisme guru dan meningkatkan kualitas pembelajaran melalui pembelajaran yang efektif.

Peneliti melakukan observasi pada Madrasah Aliyah Kabupaten Sigi untuk mendapatkan data yang lebih akurat. Agar mudah dipahami hasil observasi pertemuan individu ini, menurut penelitian cukup efektif untuk menyelesaikan problema yang dihadapi guru, baik permasalahan itu muncul dari kalangan guru maupun dari kalangan peserta didik.

Berdasarkan hasil wawancara dan hasil observasi di atas, dapat dipastikan bahwa pembinaan pengembangan profesionalisme guru melalui supervisi pertemuan individu dilaksanakan oleh pengawas.

\footnotetext{
${ }^{64}$ Farhan, Pengawas Pendidikan Agama Islam, Madrasah Aliyah Kabupaten Sigi, Wawancara.

${ }^{65}$ Darmawati, Guru Fikih, Madrasah Aliyah Al-Khairaat Pakuli Kabupaten Sigi, Wawancara,
} Sigi. 


\section{Melaksanakan Supervisi Akademik Melalui Kelompok}

Pelaksanaan supervisi akademik melalui pertemuan kelompok sebagai satu cara melaksanakan program supervisi akademik yang ditujukan pada dua orang atau lebih. Pelaksanaan supervisi akademik melalui pertemuan kelompok memberi peluang dan kesempatan seluruh potensi guru dan melibatkan guru tanpa pilih kasih dalam suatu kegiatan yang akan menunjang kematangan profesional guru.

Peneliti mewawancarai Pengawas Pendidikan Agama Islam, Madrasah Aliyah Kabupaten Sigi berkaitan dengan pelaksanaan supervisi kelompok pada Madrasah Aliyah Kabupaten Sigi.

Dalam supervisi akademik melalui pertemuan kelompok ini pengawas madrasah mengundang seluruh pengawas dan kepala madrasah untuk melakukan kerjasama dalam melaksanakan supervisi kelompok. Kemudian guru dikelompokkan atau dikumpulkan menjadi satu/bersama-sama. Kemudian pengawas menetapkan teknik pengawasan kelompok yang akan diterapkan, yaitu; kerja kelompok, demonstrasi pembelajaran, diskusi panel, pertemuan guru, dan lokakarya atau konferensi kelompok. ${ }^{66}$

Untuk memperkuat data yang diperoleh dari hasil wawancara dengan Pengawas Pendidikanpada Madrasah Aliyah Kabupaten Sigi peneliti juga melakukan wawancara dengan Kepala Madrasah Aliyah Al-Muhibba Soulowe Kabupaten Sigi, sebagai berikut:

Yang dilakukan dalam pertemuan kelompok yaitu pertama pengawas memaparkan konsep supervisi dihadapan guru dalam satu ruangan tertentu untuk menggali konsep tentang pengajaran; kedua pengawas meminta guru melakukan diskusi kelompok; ketiga pengawas memandu guru untuk melakukan analisis dan membuat laporan praktik supervisi yang baru saja dilakukan. $^{67}$

Selanjutnya penulis mewawancarai Kepala Madrasah Aliyah Al-Khairaat Pakuli Kabupaten Sigi, sebagai berikut:

Dalam pertemuan kelompok didiskusikan yang berkaitan dengan penyusunan program, penyusunan silabus, pembuatan RPP, penyajian materi pelajaran, yang ada kaitannya dengan peningkatan profesional Guru Mata Pelajaran Pendidikan Agama Islam dan peningkatan kualitas peserta didik, serta pelaksanaan kegiatan ekstrakurikuler. ${ }^{68}$

Untuk memperkuat data yang diperoleh dari beberapa kepala Madrasah Aliyah Kabupaten Sigi sebagai informan utama, maka peneliti juga melakukan wawancara dengan para guru Guru Fikih pada Madrasah Aliyah Al-Khairaat Pakuli Kabupaten Sigi, sebagai berikut:

Dalam pelaksanaan pertemuan kelompok oleh pengawas, biasanya pengawas meminta guru berkumpul dalam satu ruangan tertentu untuk menggali konsep

\footnotetext{
${ }^{66}$ Rukyan Hamid, Pengawas Pendidikan Agama Islam, Madrasah Aliyah Kabupaten Sigi, Wawancara.

${ }^{67}$ Aspan, Kepala Madrasah Aliyah Al-Muhibba Soulowe Kabupaten Sigi, Wawancara..

${ }^{68}$ Zubair, Kepala Madrasah Aliyah Al-Khairaat Pakuli Kabupaten Sigi, Wawancara.
} 
tentang supervisi kelompok, dan membuat konsep tentang aspek-aspek yang akan disupervisi. ${ }^{69}$

Peneliti wawancara dengan guru Akidah Akhlak Madrasah Aliyah Al-Khairaat Sibalaya Kabupaten Sigi, tentang pelaksanaan pertemuan kelompok sebagai berikut:

Dalam pertemuan kelompok dilakukan diskusi. Dalam diskusi tersebut peserta dibagi berdasarkan spesifikasi bidang studi, kepala madrasah memandu peserta mendiskusikan mengenai penyusunan silabus, pnyusunan rencana pelaksanaan pembelajaran, penggunaan media pembelajaran, penggunaan model, dan strategi pembelajaran serta membuat format analisis supervisi akademik, hasil diskusi secara kelompok ditulis dan diberikan kepada semua guru, juga tukar pengalaman antara guru yang telah mendapat pelatihan dengan sesama guru yang belum mendapat pelatihan. ${ }^{70}$

Berdasarkan pemaparan di atas, pengawas Madrasah Aliyah Kabupaten Sigi melaksanakan supervisi kelompok. Dalam pelaksanaan suprvisi kelompok pengawas berkomunikasi dengan kepala madrasah dan para guru agar guru benar-benar menerima bimbingan kelompok sebagai upaya pembinaan profesionalnya.

Langkah yang dilakuan pengawas Madrasah Aliyah Kabupaten Sigi dalam pembinaan adalah menciptakan hubungan yang harmonis antara pengawas, kepala madrasah dengan guru. Sebagai langkah awal setiap pembinaan keterampilan pembelajaran melalui supervisi kelompok yang mengidentifikasi guru yang baik dan yang kurang terampil dalam mengajar.

Hasil observasi menunjukkan bahwa pengawas Madrasah Aliyah Kabupaten Sigi melaksankan pertemuan orientasi rapat dengan para guru Pendidikan Agama Islam Madrasah Aliyah Kabupaten Sigi, dan melakukan diskusi, serta beberapa dokumen yang menunjukkan bukti bahwa kepala melaksanakan pertemuan kelompok.

Berdasarkan pemaparan wawancara dan hasil observasi di atas menunjukkan bahwa supervisi akademik melalui pertemuan kelompok dilaksanakan oleh pengawas dengan sangat menguasai keterampilan supervisi kelompok, sejak merencanakan, melaksanakan, menilai, mengambil kesimpulan, membahas hasil supervisi, dan melaporkan hasilnya yang disertai dengan rekomendasi penyelesaian masalah yang ditemukan di lapangan.

Pengawas Madrasah Aliyah Kabupaten Sigi memainkan peranan penting dalam peningkatan profesional Guru Mata Pelajaran Pendidikan Agama Islam melalui supervisi kelompok yakni memberikan layanan dan bantuan untuk mengembangkan situasi pembelajaran yang dilakukan guru di kelas di Madrasah Aliyah Kabupaten Sigi. Juga melalui pertemuan kelompok kpengawas membantu para guru Pendidikan Agama Islam pada Madrasah Aliyah Kabupaten Sigi untuk saling mengetahui, memahami atau mendalami suatu permasalahan, sehingga jika ada kekeliruan dalam mengungkapkan gagasan dan pikiran dapat diperbaiki. Melalui proses pertemuan kelompok dengan guru bersama-sama akan berusaha mencari alternatif pemecahan masalah dan menentukan cara terbaik untuk memecahkan masalah tersebut.

Supervisi akademik melalui pertemuan kelompok di Madrasah Aliyah Kabupaten Sigi diarahkan untuk memperbaiki Profesional Guru Mata Pelajaran

${ }^{69}$ Darmawati, Guru Fikih, Madrasah Aliyah Al-Khairaat Pakuli Kabupaten Sigi, Wawancara, Sigi.

${ }^{70}$ Kamaruddin, Guru Akidah Akhlak Madrasah Aliyah Al-Khairaat Sibalaya Kabupaten Sigi. 
Pendidikan Agama Islam pada Madrasah Aliyah Kabupaten Sigi secara totalitas berkaitan dengan tugas-tugas keguruan. Profesional Guru Mata Pelajaran Pendidikan Agama Islam pada Madrasah Aliyah Kabupaten Sigi tersebut merupakan modal dasar pembentukan watak dan prestasi peserta didik. Pelayanan pembinaan kelompok merupakan usaha preventif kepala madrasah untuk meningkatkan Profesional Guru Mata Pelajaran Pendidikan Agama Islam pada Madrasah Aliyah Kabupaten Sigi.

Sasaran supervisi akademik melalui pertemuan kelompok pada Madrasah Aliyah Kabupaten Sigi ditujukan kepada situasi pendidikan dan pengajaran yang memungkinkan tercapainya tujuan pembelajaran dengan baik. Oleh karena itu, sasaran utama dari supervisi akademik melalui pertemuan kelompok pada Madrasah Aliyah Kabupaten Sigi sebagai pembinaan kepada guru Pendidikan Agama Islam pada Madrasah Aliyah Kabupaten Sigi dalam meningkatkan profesional Guru Mata Pelajaran Pendidikan Agama Islam sehingga pelaksanaan pembelajaran berjalan dengan baik dan pelaksanaan kegiatan pendidikan seperti pengelolaan kelas, pengelolaan madrasah, pengelolaan administrasi kurikulum, pelaksanaan bimbingan, ketersediaan fasilitas pendukung pendidikan dan pengajaran serta pelaksanaan kegiatan ekstrakurikuler.

Berdasarkan hasil wawancara, observasi dan dokumentansi, maka dapat diasumsikan bahwa pengawas terbukti memberikan bimbingan bantuan dan pengawasan dan penilaian pada masalah-masalah yang berhubungan dengan tehnis penyelenggara dan pengembangan pendidikan, pengajaran yang berupa perbaikan program pengajaran dan kegiatan pendidikan pengajaran untuk dapat menciptakan situasi belajar mengajar yang lebih baik.

Pengawas Pendidikanpada Madrasah Aliyah Kabupaten Sigi telah menjalankan tugas sebagai supervisor dalam melaksanakan tugas-tugasnya dan terlihat dari hasil wawancara, observasi dan dokumentasi bahwa pengawas Pendidikanpada Madrasah Aliyah Kabupaten Sigi menjalankan tugas pembimbingan dan bantuan profesionaltas guru melalui komunikasi efektif yang merupakan media keterampilandan dilakukan juga proses interaksi baik langsung maupun tidak langsung.

Kemampuan administratif alat penting dalam mengelola lembaga agar bisa berjalan dengan baik mencapai tujuan pendidikan. Pengawas Pendidikanpada Madrasah Aliyah Kabupaten Sigi sebagai supervisor telah memiliki kemampuan merencanakan, mengorganisir personel dan sumber daya lainnya, menggerakannya serta mensupervisi para guru pada Madrasah Aliyah Kabupaten Sigi.

Kemampuan evaluasi diperlukan berkaitan dengan peran pengawas Pendidikanpada Madrasah Aliyah Kabupaten Sigi sebagai supervisor mampu membimbing dan membantu guru memberi informasi dan bahan-bahan yang tepat mengenai akar permasalahan yang ditemui guru. Kemampuan evaluasi oleh pengawas Pendidikanpada Madrasah Aliyah Kabupaten Sigi amat sangat diperlukan. Mana mungkin seorang supervisor mampu memberikan bantuan profesional guru jika ia tidak memiliki sumber daya yang efektif untuk menjawab permasalahan-permasalahan yang dihadapi guru-guru.

Supervisi yang dilaksanakan oleh pengawas Pendidikanpada Madrasah Aliyah Kabupaten Sigi sangat mendukung kematangan professional guru karena pengawas Pendidikanpada Madrasah Aliyah Kabupaten Sigi bertugas membina guru untuk semangat dan motivasi kerja guru serta membantu menjawab permasalahan- 
permasalahan yang dihadapi guru-guru sehingga melahirkan profesional Guru Mata Pelajaran Pendidikan Agama Islam.

\section{PENUTUP}

Berdasarkan paparan di atas, maka dapat disimpulkan bahwa penerapan Supervisi Akademik Pengawas Pendidikan pada Madrasah Aliyah Kabupaten Sigi berjalan dengan baik karena (1) pengawas memiliki kemampuan merencakan supervisi akademik yang meliputi keseluruhan proses pemikiran dan penentuan cara yang matang dari kegiatan-kegiatan yang akan dikerjakan dalam melakukan supervisi akademik, dalam rangka pencapaian tujuan khususnya untuk pembinaan profesional guru di madrasah; dan (2) kemampuan pengawas telah pengoptimalan pelaksanaan supervisi akademik melalui supervisi individu dan kelompok yang sangat membantu kematangan profesional Guru Mata Pelajaran Pendidikan Agama Islam pada Madrasah Aliah Kabupaten Sigi dimana sebagai pembimbingan kepada guru dalam menyusun silabus dan RPP; memilih dan menerapkan metode pembelajaran, mengelola menggunakan media pembelajaran, dan pembimbingan melaksnakan evaluasi pembelajaran.

\section{DAFTAR PUSTAKA}

Gunawan, Ary, Supervisi dan Peningkatan Mutu Pendidikan Cet. II; Yogyakarta: Adicita Karya Nusa, 2001.

Kasman, "Model Supervisi Individu dan Kelompok dalam Supervisi Pembelajaran", Al-Buhust, Malang: Jurnal Penelitian, 2010.

Kastomo, E., Supervisi Pendidikan, Cet. II; Bandung: Alfabeta, 2007.

Makawimbang, Jerry, Supervisi dan Peningkatan Mutu Pendidikan, Cet. I; Bandung: Alfabeta, 2011.

Mulyasa, Kurikulum Berbasis Kompetensi Konsep, Karakteristik, dan Implementasi Cet. XII; Bandung: Remaja Rosdakarya, 2015.

Pidarta, Made, Pemikiran Tentang Supervisi Pendidikan, Jakarta: Bumi Aksara, 2009.

Republik Indonesia, Undang-Undang RI Sistem Pendidikan Nasional Nomor. 20 Tahun 2003.

Sahertian, Piet A., Konsep Dasar dan Teknik Supervisi Pendidikan dalam Rangka Pengembangan Sumber Daya Manusia, Cet. II; Jakarta: Rineka Cipta, 2001.

Sahertian, Piet A., Prinsip dan Teknik Supervisi Pendidikan, Cet. I; Surabaya: Usaha Nasional, 1981

Soemanto Wasty, Kepemimpinan dan Supervisi Pendidikan, Cet. V: Malang: Bumi Aksara, 2002. 
Syaefuddin, Supervisi Pendidikan, Cet. III; Jakarta: Rineka Cipta, 2005.

Syaiful Sagala, Supervisi Pembelajaran dalam Profesi Pendidikan; Membantu Mengatasi Kesulitan Guru Memberikan Layanan Belajar yang Bermutu, Cet. II; Bandung: CV. Alfabeta, 2010

\section{Sumber Wawancara}

Agustina, Kepala Madrasah Aliyah DDI Lonja Kabupaten Sigi

Asma, Kepala Madrasah Aliyah Al-Khairaat Pulu Dolo Kabupaten Sigi

Aspan, Kepala Madrasah Aliyah Al-Muhibba Soulowe Kabupaten Sigi

Darmawati, Guru Fikih, Madrasah Aliyah Al-Khairaat Pakuli Kabupaten Sigi

Farhan, Pengawas Pendidikan Agama Islam, Madrasah Aliyah Kabupaten Sigi,

Farhana Azzahra, Guru Al-Qur'an Hadis, Madrasah Aliyah Wumbulangi Kabupaten Sigi.

Fildan Ahmad, Guru Akidah Akhlak, Madrasah Aliyah Al-Muhibba Soulowe Kabupaten Sigi

Fitriani, Kepala Madrasah Aliyah, al-Khairaat Kabeloa Pewunu Kabupaten Sigi

Ismail Syam, Guru Akidah Akhlak, Madrasah Aliyah al-Khairaat Kabeloa Pewunu Kabupaten Sigi

Kamaruddin, Guru Akidah Akhlak Madrasah Aliyah Al-Khairaat Sibalaya Kabupaten Sigi.

Muhazzab, Pengawas Pendidikan Agama Islam, Madrasah Aliyah Kabupaten Sigi

Rajamuddin, Guru Fikih, Madrasah Aliyah Al-Khairaat Pulu Dolo Kabupaten Sigi.

Rukyan Hamid, Pengawas Pendidikan Agama Islam, Madrasah Aliyah Kabupaten Sigi.

Taif Talib, Kepala Madrasah Aliyah Al-Khairaat Sibalaya Kabupaten Sigi.

Usman, Pengawas Pendidikan Agama Islam, Madrasah Aliyah Kabupaten Sigi.

Wahab Badry, Pengawas Pendidikan Agama Islam, Madrasah Aliyah Kabupaten Sigi.

Zubair, Kepala Madrasah Aliyah Al-Khairaat Pakuli Kabupaten Sigi. 